III) Nordic Council of Ministers

\title{
Nordic labour markets and the sharing economy
}

- REPORT FROM A PILOT PROJECT 



\section{Nordic labour markets and the sharing economy}

-Report from a pilot project

Jon Erik Dølvik and Kristin Jesnes

TemaNord 2018:516 


\author{
Nordic labour markets and the sharing economy \\ - Report from a pilot project \\ Jon Erik Dølvik and Kristin Jesnes \\ ISBN 978-92-893-5460-8 (PRINT) \\ ISBN 978-92-893-5461-5 (PDF) \\ ISBN 978-92-893-5462-2 (EPUB) \\ http://dx.doi.org/10.6027/TN2018-516 \\ TemaNord 2018:516 \\ ISSN 0.908-6692 \\ Standard: PDF/UA-1 \\ ISO 14289-1 \\ (c) Nordic Council of Ministers 2018 \\ Cover photo: unsplash.com \\ Print: Rosendahls \\ Printed in Denmark

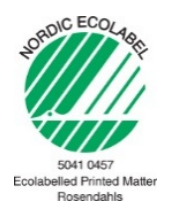

\title{
Disclaimer
}

This publication was funded by the Nordic Council of Ministers. However, the content does not necessarily reflect the Nordic Council of Ministers' views, opinions, attitudes or recommendations.

\section{Rights and permissions}

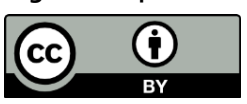

This work is made available under the Creative Commons Attribution 4.0 International license (CC BY 4.0) https://creativecommons.org/licenses/by/4.0

Translations: If you translate this work, please include the following disclaimer: This translation was not produced by the Nordic Council of Ministers and should not be construed as official. The Nordic Council of Ministers cannot be held responsible for the translation or any errors in it.

Adaptations: If you adapt this work, please include the following disclaimer along with the attribution: This is an adaptation of an original work by the Nordic Council of Ministers. Responsibility for the views and opinions expressed in the adaptation rests solely with its author(s). The views and opinions in this adaptation have not been approved by the Nordic Council of Ministers. 
Third-party content: The Nordic Council of Ministers does not necessarily own every single part of this work. The Nordic Council of Ministers cannot, therefore, guarantee that the reuse of third-party content does not infringe the copyright of the third party. If you wish to reuse any third-party content, you bear the risks associated with any such rights violations. You are responsible for determining whether there is a need to obtain permission for the use of third-party content, and if so, for obtaining the relevant permission from the copyright holder. Examples of third-party content may include, but are not limited to, tables, figures or images.

Photo rights (further permission required for reuse):

Any queries regarding rights and licences should be addressed to:

Nordic Council of Ministers/Publication Unit

Ved Stranden 18

DK-1061 Copenhagen K

Denmark

Phone +4533960200

pub@norden.org

\section{Nordic co-operation}

Nordic co-operation is one of the world's most extensive forms of regional collaboration, involving Denmark, Finland, Iceland, Norway, Sweden, and the Faroe Islands, Greenland and Åland.

Nordic co-operation has firm traditions in politics, economics and culture and plays an important role in European and international forums. The Nordic community strives for a strong Nordic Region in a strong Europe.

Nordic co-operation promotes regional interests and values in a global world. The values shared by the Nordic countries help make the region one of the most innovative and competitive in the world.

The Nordic Council of Ministers

Nordens Hus

Ved Stranden 18

DK-1061 Copenhagen K, Denmark

Tel.: +4533960200 www.norden.org

Download Nordic publications at www.norden.org/nordpub 



\section{Contents}

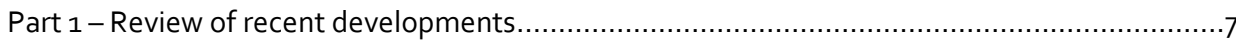

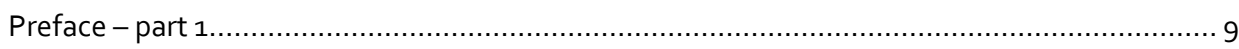

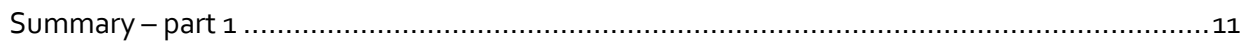

Platform work in the Nordic countries: A review of recent developments 2017-2018 ..............13

1 The scope of platform work - stagnation or exponential growth? ...............................13

2 An illustration: The diverging pathways of Uber in the Nordic countries ........................17

3 Changing forms of work, employment relations, and policy responses ........................ 19

4 Challenges to employment relations and work environment ..................................... 20

5 Social partner responses to the sharing economy, digitalization, and new forms of work 24

6 Platform work plays into broader labour market trends ........................................... 26

Part 2 - Nordic labour markets and the sharing economy - report from a pilot project ..............31

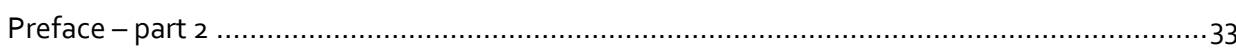

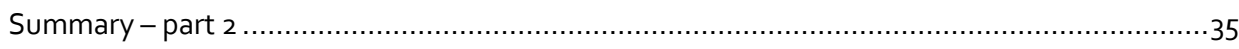

1. Background and context: What is the sharing economy and how can it be governed? ........37

$1.1 \quad$ How to denominate and define the sharing economy? ..................................... 37

1.2 What are the concerns and interests of the governments and the social partners? .. 39

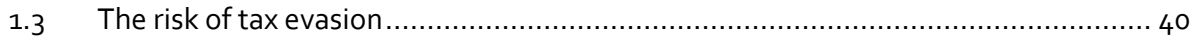

1.4 Distortion of competition: How to maintain a level playing field? ..............................

1.5 Changing employment relationships? ......................................................43

2. Platform work: implications for employment relations and the broader labour market...... 45

2.1 The size of the Nordic platform labour market ................................................ 46

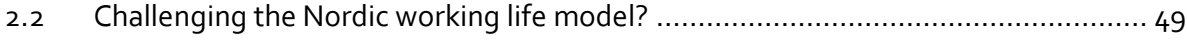

2.3 Social partner and governmental responses on work life issues ............................63

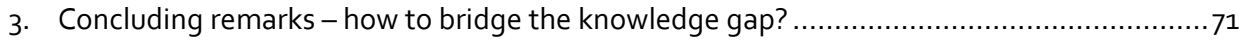

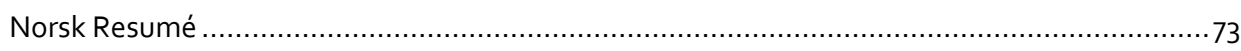

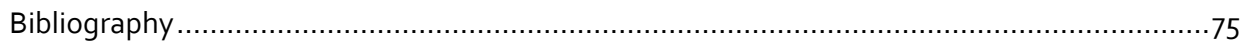

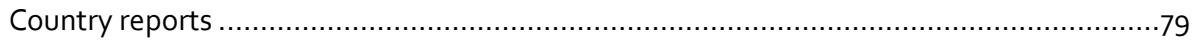





\section{Part 1 - Review of recent developments}





\section{Preface - part 1}

Platform work is a relatively new field of study and developments take place almost weekly. This review is an update of the main developments since the report "Nordic Labour Markets and the Sharing Economy - Report from a Pilot Project" (Dølvik \& Jesnes, 2017: 508) was published a year ago. This updated version of the report builds on observations of recent policy developments, policy papers, newly published research, and the conference "Shaping the Future of Work in the Nordic Countries - the Impacts of the Sharing Economy and New Forms of Work" held in Oslo, 22-23 May 2017. Organized by the Norwegian Ministry of Labour and Social Affairs, in collaboration with Fafo, this was the second out of four annual Nordic conferences leading up to the Future of Work debate on ILO's centenary anniversary in $2019 .{ }^{1}$ Hosting prominent international keynote speakers, the conference gathered more than 100 participants from politics, public authorities, social partners, business, ${ }^{2}$ researchers and experts from all of the Nordic countries and beyond. Funding the conference, the Norwegian Ministry of Labour and Social Affairs, together with the Nordic Council of Ministers, also provided financial support for this updated review aimed to stimulate dialogue across Nordic boundaries and to provide basis for Nordic input to the ILO Future of Work process.

Oslo, January 2018

Jon Erik Dølvik \& Kristin Jesnes

Link to presentations from the conference can be found here:

https://www.fafo.no/index.php/nb/arrangementer/alle-arrangementer/item/slides-from-the-futureof-work-in-the-nordic-countries

\footnotetext{
${ }^{1}$ In preparation for its centenary conference in 2019, the ILO has asked the Nordic countries to contribute with ideas on how to shape the future of work. The Oslo conference therefore had three goals: (i) to present new knowledge and research on the future of work in the Nordic countries, focusing on the sharing/platform economy, (ii) to facilitate discussions between social partners in the Nordic countries, (iii) to form a basis for input to the ILO's future of work debates. The program included international perspectives on the sharing economy, presentations of national governmentappointed investigations, research from the Nordic countries, social partner views, and company perspectives. All slides from the conference can be found here: https://www.fafo.no/index.php/nb/arrangementer/alle-arrangementer/item/slidesfrom-the-future-of-work-in-the-nordic-countries

${ }^{2}$ Cool Company, Ework and Finn småjobber (small jobs) presented their business concepts, while Uber attended the conference as a participant.
} 



\section{Summary - part 1}

Part 1 of this report is an update of the main developments since the report "Nordic Labour Markets and the Sharing Economy - Report from a Pilot Project" (Dølvik \& Jesnes, 2017: 508) was published a year ago, which is now part 2 in this report. This updated version of the report builds on observations of recent policy developments, policy papers, newly published research, and the conference "Shaping the Future of Work in the Nordic Countries - the Impacts of the Sharing Economy and New Forms of Work" held in Oslo, 22-23 May 2017. 



\section{Platform work in the Nordic countries: A review of recent developments 2017-2018}

The TemaNord report Nordic labour markets and the sharing economy - report from a pilot project (Dølvik \& Jesnes, 2017: 508) describes the status of knowledge about work in the emerging Nordic sharing economies. In this updated version of the report, we apply the terms platform economy and platform work, which we consider more appropriate to describe the new forms of work mediated through digital platforms. The platform economy as a field of research is rapidly evolving. Nordic governments have established investigative committees and advisory councils, issued reports, financed research and started shaping policies aimed at facilitating the evolution of these novel labour market agents and their integration into the Nordic models. The aim of this review is to provide information about the main developments in the field since the pilot report was published one year ago, and, in line with the Future of Work conference held in Oslo, 22-23 May 2017, to relate the debates on platform work to the broader discussions about digitalization and the future of work. First, we review recent research findings regarding the scope, pace of growth, and heterogeneity of platform work. Second, we revisit some of the past year's policy developments and the main points from the conference discussions between academics and social partners regarding approaches to regulation and governance of platform work. As platform work is part of broader transformations of work, we, finally, review the conference discussions about the impact of digitalization on the labour market and the need for further knowledge about the changes such trends might lead to in Nordic working lives.

\section{The scope of platform work - stagnation or exponential growth?}

A striking feature at the Oslo Future of Work conference was the extent to which the platform work debate had changed from what several participants saw as "hyped" expectations two years earlier to more nuanced, "down-to-earth" approaches as more knowledge and experience had become available. In contrast to prior prophecies of "exponential growth" in platform work, evidence indicating that platform work was still marginal in the Nordic labour markets had clearly had a sobering effect. Since the conference in May 2017, several new studies have confirmed that the number of Nordic platform workers remains limited, indicating that the pace of growth has been slow, if there has been any at all. In fact, the shutdown of UberPop's operations in several 
Nordic countries ${ }^{3}$ suggests that employment in this area declined in 2017. As data are not yet available from Finland and Iceland, this section first reviews main research findings regarding the scope of platform work in Denmark, Norway and Sweden, and then briefly points to factors that are likely to influence further developments.

Table 1: Scope of platform work in Denmark, Norway and Sweden

\begin{tabular}{|c|c|c|}
\hline Country & Number of people having worked via platform during the past year & Source \\
\hline Denmark & Around $1 \%$ of working age population & Ilsøe \& Madsen 2017 \\
\hline Norway & $0.5-1 \%$ of working age population & Alsos et al. 2017 \\
\hline Sweden & Around $2.5 \%$ of working age population & SOU 2017: 24 \\
\hline
\end{tabular}

As illustrated in table 1 , the overall numbers of people in these countries performing work mediated through a platform in the past year remain low. Although the figures for Sweden are actually higher than for agency work in terms of numbers, the amount of work performed by people who have found jobs via platforms is, except for a few cases, very modest, and the work is often sporadic. This suggests that for most participants, platform work serves as an occasional source of extra income. Whether the crossnational variations seen in the table reflect real differences in the prevalence of such work or are due to methodological differences between the studies is hard to judge, ${ }^{4}$ underscoring the need for comparative studies based on common methodology and data sources.

A study on ICT-based mobile work and platform work in Sweden 2016, commissioned by a governmental committee examining the impact of new labour market trends on the working environment (SOU, 2017: 24), indicates that around 4 per cent of working age Swedes had tried to get an assignment via a digital platform in 2016. ${ }^{5}$ Applying for jobs through digital platforms was more common among younger people (16-24 years old) than older people, and more common among men than women. As an urban phenomenon, it was also more common among people born outside of Sweden. Only 56 per cent of these potential platform workers had actually performed work via a platform, corresponding to about 2.5 per cent of the working age population - roughly 150,000 persons (Ibid: 204). The survey indicated that 44 per cent of these conducted work within data and IT; 25 per cent within administration, economic or legal issues; 22 per cent within culture, media and design; 18 per cent within educational work; 12 per cent within transport of good; and 8 per cent within transport of personnel. The most common platforms were Offerta, UberPop and Taskrunner. The survey also confirmed that for most participants in this type of work is

\footnotetext{
3 UberPop has also pulled out of several other European countries, including Germany, the Netherlands and Spain. The Norwegian Board of Technology has gathered information on how countries are regulating the sharing economy on the following website: https://list.ly/list/1LxA-regulating-the-sharing-economy

4 The Danish study applied a quite narrow definition of platforms mediating work in the sense that they asked if you had performed work through specific platforms, resulting in a conservative estimate (Ilsøe \& Madsen, 2017: 39), and the same pertains to the Norwegian study (Alsos et al., 2017).

5 Examples of digital platforms in Sweden are Uber, Urb-it, Baghitch, Taskrunner, Offerta, Upwork, Freelancer, 99designs, Just Arrived, Servicefinder and Lego Idea.
} 
sporadic. The majority (6o per cent) worked less than 10 hours per month, and 36 per cent worked less than 5 hours per month. For most of those having tried platform work, this accounted for less than 25 per cent of their total income. Yet, some people seemed to work quite a lot through platforms (at least 30 hours a week) and 14 per cent earned more than half of their income through such platforms. The majority (70\%) of those who performed work through digital platforms did not receive student grants, student loans, unemployment benefits or other remuneration (Ibid: 205). In addition to presenting figures on platform work, the report showed that the number of selfemployed without employees had increased from about 310,000 in 1993 to about 890,000 in 2016 (Eriksson, 2017).

In Denmark, a recent report from FAOS analysed experiences with digitalization and digital platforms in the Danish labour force (Ilsøe \& Madsen, 2017). Based on an adhoc module of the Danish labour force survey in 2017, the study included 18,000 respondents aged $15-74$ years. The results show that platform work remains a marginal phenomenon in Denmark. During the past year, only 1 per cent (about 42,000 persons) had earned money through labour platforms, such as Happy Helper (cleaning), Upwork (office work), Worksome (academic work) or Uber (transport). Moreover, for most Danish platform workers, earnings through platforms were only a minor supplement to other sources of income (salary, pensions, student allowances, unemployment benefits, social assistance etc.). Among those having performed platform work, there was an overrepresentation of young, low-paid and low-skilled persons with temporary jobs or unemployed. Danes with ethnic minority background were also overrepresented. This suggests that many of those working through platforms are either new entrants or struggling to get a foothold in the labour market. This is in stark contrast to Danes earning money through capital platforms, a group dominated by highly educated and highly paid groups (Ilsøe \& Madsen, 2017). This indicates that there is a class dimension to the opportunities offered by the platform economy.

In Norway, a recent study undertaken by Fafo estimates that $0.5^{-1}$ percent, between 10,000 and 30,000 individuals, had conducted platform work during the past year (Alsos et al., 2017). The numbers are so small that the researchers have chosen not to analyse the data on different background variables. Yet, the Fafo study included data and information received from the Norwegian Tax Administration about those driving for UberPop in 2016. ${ }^{6}$ According to several studies, Uber is the second largest labour platform in Norway after Finn småjobber (small jobs) (Slettemeås \& Kjørstad, 2016; Jesnes et al., 2016). In 2016, UberPop had 1, 298 active drivers in Norway, earning a total of NOK 114 million (after Uber had taken its 25 per cent cut) (Ibid: 57). The total revenue for UberPop in Norway in 2016 was about NOK 140 million. Almost nine out of ten drivers ( 87 per cent) were men, and the majority (68 per cent) were over 30 years old. Lacking data on the drivers' country of origin, the analysis points out that very few had

\footnotetext{
${ }^{6}$ Fafo has been in touch with the Norwegian Tax Administration during the fall of 2017 to receive data and information about Uber drivers in Norway, their income, age, gender, country background for research purposes (Alsos et al. 2017: 56 58). The Norwegian Tax Administration has on several occasions been interviewed in media, where some of these numbers have been revealed. However, this is the first comprehensive overview of the Uber drivers in Norway.
} 
Norwegian names with most names indicating that the drivers had a background from Eastern Europe, Asia, or Africa. Whether such (hitherto illegal) assignments served as a stepping stone to the ordinary labour market - often used as an argument for facilitating platform work (NOU, 2017: 4) - or rather as a scarring experience, is unknown. At any rate, the data indicate that for many of the Uber drivers in Norway, this was casual work, providing only a minor income supplement. Almost half of them (43 per cent) earned less than 25,000 NOK over the year - indeed a small extra income - and some only earned a few hundred NOK (Kapital 2017). Still, a similar share ( 42 per cent) earned over NOK 50,000, and one out of ten earned more than NOK 200,000. The latter is less than half of the average earnings in a full-time Norwegian job. It is highlighted by the Tax Administration that many earning income from Uber driving simultaneously receive income benefits from the welfare system (Alsos et al., 2017: 57), which indirectly functions as a subsidy of the low-paid Uber operation.

While several research reports have argued that the platform economy will grow rapidly (Pedersen et al., 2016; Berg \& Kjørstad, 2017), the studies done by Fafo suggest that there was no growth in the number of labour platforms compared to one year earlier (Alsos et al., 2017; Jesnes et al., 2016). Danish data point in a similar direction, indicating that many of the Danish labour platforms have difficulties covering their costs and debt interest (Ugeavisen $A_{4}, 8$ June 2017). As it is often hard to distinguish platform companies from other companies that have been around for a while, the Fafo report also notes a tendency of traditional companies to take over the concepts promulgated by the platforms, such as on-demand work and tasks being distributed or performed through new digital technology (Alsos et al., 2017). Therefore, they suggest, we might perhaps in a few years no longer talk about a distinct platform or sharing economy but see growing integration of platform methodology in ordinary companies, such as on-demand work, digitally intermediated work and increased digitalization of traditional jobs (Ibid, 2017).

In the flora of labour platforms, companies that assist freelancers in organizing their relationship with public authorities - so-called umbrella companies - have also recently emerged. Exemplified by the Cool Company, which presented its activities at the Oslo conference (Becker, 2017), these companies offer those working through platforms as freelancers or self-employed a temporary employment contract during the periods when they perform occasional jobs/tasks. The freelancers are themselves responsible for obtaining tasks. There are about 19,000 "umbrella employed" persons in Sweden - four times as many as in 2011 - and many of them, typically high-skilled experts or academics taking on extra assignments, combine this with their main standard job. On average, work for "umbrella" companies accounts for about 7 hours a week (SOU, 2017:24: 167).

Despite the present low levels and slow pace of growth, the scope for platform work in the Nordic countries in the years to come is hard to assess. Much will depend on regulatory and judicial developments, as illustrated by a European Court of Justice 
(ECJ) verdict in a recent case against Uber. ${ }^{7}$ The supply of labour willing to accept the uncertainties associated with current forms of platform work will evidently depend on the development in ordinary employment opportunities. That is, like in other nascent branches, the rate of growth in platform work is not determined by technological dynamics alone but depends on economic conditions and market demand, as well as on development in policies and institutional frameworks.

\section{An illustration: The diverging pathways of Uber in the Nordic countries}

A case in point in this regard is the bumpy ride of Uber in the Nordic countries. One year ago, Uber was the dominant platform company in the Nordic countries. This is, for the time being at least, no longer the case. During 2017, Uber's dominant business model, UberPop, built on the claim that it was an ICT company and that those working for it were independent contractors, increasingly met with obstacles. ${ }^{8}$ In a range of court cases, including in London, judges did not accept Uber's claim that their drivers were independent freelancers (London Employment Tribunal 2016 in Dølvik \& Jesnes, 2017: 16). A further obstacle arose when the ECJ concluded in late 2017 that Uber was not an ICT provider but a transport company, subject to the same national rules as any other transport company in the EU/EEA Member States (CJEU, Case C-434/15). Prior to this path-breaking decision, the Nordic governments had pursued different approaches to the Uber operations in their countries, and the company had responded in different ways.

So far, Denmark and Sweden have enforced traditional transport regulations for UberPop. In Denmark, Uber closed down its UberPop operations in March 2017 due to amendments in the taxi law. The amended law, outlined in the agreement Modernisering af taxiloven (9 February 2017), lifts restrictions on the number of taxi licenses, but still obliges all taxis to have a taximeter and seat sensors for tax purposes, to be connected to a transport central, and drivers must have at least two weeks of training. ${ }^{9}$ Although this made it difficult to continue the UberPop model, according to the company, and operations in Denmark were closed down, Uber still retains 40 employees in Aarhus working on developing service concepts and the app..$^{10}$ In Sweden, Uber suspended its activities in 2016 after repeated court verdicts implying that UberPop amounted to a pirate taxi business..$^{11}$ There have been some discussions about liberalizing the personal transport industry in Sweden, but in November 2016, the report of a government-appointed committee - Taxi och samåkning - $i$ dag, i morgon

\footnotetext{
7 In late 2017, the ECJ ruled that Uber is to be regarded as a transport service company, and not as a technology company, see https://curia.europa.eu/jcms/upload/docs/application/pdf/2017-12/cp170136en.pdf

${ }^{8}$ Uber still operates in several of the Nordic countries through other services such as UberBlack or UberXL, but the market for these types of services seems to be more limited than for UberPop.

${ }_{9}$ Agreement on taxi law in Denmark: https://www.trm.dk/da/politiske-aftaler/2017/stemmeaftale-om-modernisering-aftaxiloven

${ }^{10} \mathrm{http}: / /$ politiken.dk/oekonomi/art5889910/Ny-taxilov-f\%C3\%A 5 r-Uber-til-at-lukke-i-Danmark

${ }^{11}$ https://www.dn.se/ekonomi/uber-tvarvander-lagger-ned-omstridda-tjansten/
} 
och i övermorgon (SOU, 2016: 86) - concluded that a strict distinction between taxi services and carpooling was required. Accordingly, UberPop drivers would have to obtain a permit from the Transport Agency to operate, in practice rendering the UberPop model unviable in Sweden. As a consequence, the operation was closed down.

In Finland and Norway, the legal frameworks have been comparable to those in Denmark and Sweden, but the governments early on adopted more forthcoming policy approaches to allow for Uber's UberPop service. In Finland, the government adopted new taxi regulations in 2017, to be implemented from July 2018 (Lag om transportservice, 320/2017). ${ }^{12}$ According to the new law, taxi services still require a license, but there is no longer a limit on the number of licenses. In addition, drivers must have a command of the Finnish language, have a clean criminal record, and be able to assist customers with special needs (Saloniemi 2016 in Dølvik \& Jesnes, 2017). This new regulation might seem to open the streets for UberPop, as the company is set to relaunch its services in Finland in the summer of 2018. ${ }^{13}$

After a period of governmental ambiguity surrounding UberPop's activity in Norway - shifting between praise for the service and police crackdowns on drivers for lack of permits and failure to pay tax - the Norwegian government finally presented its future taxi policy in late 2017, the last among the Scandinavian governments to do so. After EFTAs Surveillance Authority (ESA) sent an opinion to the Norwegian government in February 2017 - stating that the transport law regulations of taxibusiness were in breach of EU/EEA rules - the government answered ESA in December 2017, announcing that it would initiate reforms of the taxi industry. ${ }^{14}$ According to the Ministry, the new regulations will accommodate Uber. ${ }^{15}$ What is known so far is that the proposal for new regulations will include lifting of restrictions on the number of taxi licenses as well as removing the requirement that all taxis have to be connected to a transport central. So far, the proposed changes in the Norwegian regulations of taxi transport seem to be more liberal than the amended regulations in Denmark, but probably more restrictive than in Finland. Whether the liberalization will suffice for Uber to relaunch service along the lines of UberPop remains to be seen. Yet, after the ECJ verdict and changes in Uber leadership it seems that the company has realized that if it wants to continue doing business within the EU/EEA, it has to adjust to the national transport regulations in Europe.

\footnotetext{
${ }^{12}$ https://www.finlex.fi/sv/laki/alkup/2017/20170320

${ }_{13}$ https://www.hbl.fi/artikel/uber-tar-timeout-ett-ar/

${ }_{14} \mathrm{https} / / / \mathrm{www}$.regjeringen.no/no/aktuelt/igangsetter-arbeid-for-a-endre-drosjereguleringen/id2581606/

15 https://www.dn.no/nyheter/2017/12/11/1413/Samferdsel/regjeringen-vil-lempe-pa-drosjekravene
} 
Although Uber is a special case, it illustrates that the conditions and avenues for growth in platform work are highly contingent on political and judicial developments, not only nationally, but also supranationally. While Nordic governments thus far have adopted somewhat different strategies as far as the contested UberPop concept and taxi policies are concerned, there is reason to believe that the potential for mutual policy learning and experience exchange will increase as the infant platform labour market matures and more comparable data and studies become available. While many early forecasts of growth in platform work were premised on strong job growth in the transport sector, the pace of change associated with new forms of personal transport, including driverless vehicles, and the unclear impact of these new modes of transport on traditional jobs make any assessment of the net effects on future employment and forms of work in this terrain highly uncertain.

\section{Changing forms of work, employment relations, and policy responses}

Mediation of labour through digital platforms challenges the employment relationship around which the Nordic labour and welfare models are built. By denying employer responsibility and using algorithms and data to match demanders and suppliers of short-term work, so-called gigs, digital platforms tend to disrupt the traditional ties between workers and employers. Presenting themselves as technical matching devices or intermediaries between independent buyers and suppliers of labour - where the latter are viewed as freelancers or solo self-employed workers - the platforms, which mediate triangular exchanges between the involved actors, form part of a purely contractual market relationship. Thereby, the package of mutual obligations and rights associated with the traditional employment relationship tends to dissolve, while the management functions become automated and faceless.

In the article "Working with Machines: The Impact of Algorithmic and Data-Driven Management on Human Workers" (Lee et al., 2015), the authors describe how the ridesharing apps Uber and Lyft use data and algorithms in managing work processes and job distribution. They coin the term "algorithmic management" to describe this business model. Data from user registration, customer ratings, and GPSs are fed into algorithms matching demanders and suppliers of labour, replacing traditional management functions. In the upcoming book Humans as a Service - The Promise and 
Perils of Work in the Gig Economy, Prassl (2018) emphasizes that using algorithms as a management tool can have both positive and negative repercussions. On the one hand, it can facilitate better allocation of work tasks - within and between firms - and improve the matching of supply, demand, and expertise/skills in the labour market. On the other hand, it can have profound consequences for the social and economic importance of work as we know it, and for the workplace. In a Nordic context, one might add consequences for the cultural and political salience of work and the institutions and power relations built around it.

During the past year, Nordic governments, social partners, researchers, and others have issued reports, conducted investigations, and come up with regulatory proposals regarding platform work. In this section, we briefly review some of the proposals presented at the Oslo conference by official representatives and academics along with some of the organized actor views regarding how to handle the employment relations and work environment challenges arising from platform work.

\section{Challenges to employment relations and work environment}

Early in 2017, a Swedish governmental committee including the social partners published a green paper titled Work Environment Rules - Regulations for a Modern Working Life (SOU, 2017: 24), and the Norwegian sharing economy commission launched its report The Sharing Economy-Opportunities and Challenges (NOU, 2017: 4). Presented at the Oslo conference by the groups' respective leaders, both reports were important references for the ensuing discussions. In Denmark, the government set up a Disruption Council in late 2016. Eventually this was followed up by the publication of a white paper titled Strategy for Growth through the Sharing Economy (Danish government 2017) ${ }^{16}$ in October 2017 along with reforms in the unemployment benefit system aimed at securing protections for platform workers.

\footnotetext{
${ }^{16} \mathrm{https}: / /$ em.dk/nyheder/2017/10-og-strategi-for-deleokonomi
} 
Table 3: Overview of governmental committees, reports, and policy proposals relating to platform work

\begin{tabular}{|c|c|c|}
\hline Country & $\begin{array}{l}\text { Governmental committees, reports or } \\
\text { policies }\end{array}$ & Proposals \\
\hline Sweden & $\begin{array}{l}\text { Work Environment Rules - Regulations for a } \\
\text { Modern Working Life } \\
\text { (SOU, 2017: 24) }\end{array}$ & $\begin{array}{l}\text { No proposals, but strong emphasis on the blurring of } \\
\text { work environment responsibilities arising from the } \\
\text { proliferation of multilateral labour relationships. }\end{array}$ \\
\hline Norway & $\begin{array}{l}\text { Sharing Economy-Opportunities and } \\
\text { Challenges (NOU 2017: 4) }\end{array}$ & $\begin{array}{l}\text { Partial deregulation of the taxi business. } \\
\text { No change in individual labour law. } \\
\text { Proposal of collective bargaining rights for platform } \\
\text { labour. }\end{array}$ \\
\hline Denmark & Disruption Council & No proposals noted thus far. \\
\hline Denmark & $\begin{array}{l}\text { Strategy for Growth through the Sharing } \\
\text { Economy (Danish government 2017) }\end{array}$ & $\begin{array}{l}\text { Considering simplifying concepts like "erhvervs- } \\
\text { drivend" and "consumers", guidance of } \\
\text { unemployment funds and job centres on the } \\
\text { application of social benefit rights. }\end{array}$ \\
\hline Denmark & $\begin{array}{l}\text { Amendments in unemployment insurance } \\
\text { scheme agreed with the social partners }\end{array}$ & $\begin{array}{l}\text { Income earned through self-employment and } \\
\text { employment contracts will be entitled to } \\
\text { unemployment benefits on an equal basis from July } \\
2018 \text {. }\end{array}$ \\
\hline
\end{tabular}

As discussed in SOU (2017: 24) and NOU (2017: 4), platform work and other multilateral forms of work tend to blur the distinctions between employers and purchasers of market services, between employees, self-employed persons, and suppliers of market services, and thus between actors with responsibility for work environment at the site of work. An idea often voiced in debates over how to close the gaps opening in labour law and social law from the various forms of platform work is to construct a new, third hybrid category between employees and self-employed (see for instance Taylor et al. 2017). In his keynote speech at the conference, Jeremiah Prassl (2017) questioned the idea of a third category, suggesting it would only amplify the delineation problems already marring political and judicial debates. Instead, he referred to his earlier works suggesting a rethinking of the way present legal categories are applied and interpreted, calling for a more integrated, functional approach (Prassl \& Risak, 2016; see also Hotvedt, 2016; Dølvik \& Jesnes, 2017). As a corollary, Prassl (2017) argued for a strengthening of the basic social and labour rights of self-employed persons, mentioning for instance that making "platform ratings" portable would strengthen the position of platform workers.

Another proposal often voiced in the debate is to redefine the notions of employer and employee. The Norwegian sharing economy committee (NOU, 2017: 4) recognized that platform work may blur such legal distinctions, but concluded that it does not challenge the legal concepts of "employee" and "employer" in a manner that cannot be properly handled by the courts. At the conference, the committee leader, Tommy S. Gabrielsen, emphasized that the problem was proper enforcement of the law rather than the law in itself (Gabrielsen, 2017). This view was well received by the employer associations, whereas all four trade union confederations in Norway-LO, Unio, YS, and Akademikerne - issued a joint call for tripartite cooperation in handling these 
quandaries immediately after the report was launched. They also sent a letter to the prime minister calling for the appointment of a committee with expertise on labour law to reassess the notion of employer and employee in the Working Environment Act and the implications of platform work for health, environment and safety (HES). ${ }^{17}$ The prime minister answered that such issues were to be discussed in a permanent, tripartite body named Arbeidslivs- og pensjonspolitisk råd (Council on Working Life and Pension Policies), where the issues raised in the letter by the social partners was on the agenda 7 December 2017.

In her conference introduction - "Rethinking the regulatory frameworks of work, employers, and labour relations" - Marianne J. Hotvedt (2017) argued, with reference to the scant jurisprudence regarding temporary work, that the courts would hardly be a suitable arena in which to resolve all the unclear cases that are likely to occur in this blurred terrain. Recalling that the Nordic countries have pretty similar legislation and legal practice when it comes to identification of employer responsibilities and who is to be covered by employee rights, she suggested the renewal of the "contract of employment test" to help clarify cases in the "gray zone" between employees and selfemployed. To advise actors that are uncertain about how to proceed in such instances, and to offer help resolving disagreements before they end up in protracted, costly court cases, she also suggested establishing a low-threshold public nemnd (agency) authorized to handle such cases at a pre-judicial stage. These ideas are elaborated in a forthcoming article, which opens with the following question: "When does the freedom to choose tasks and hours indicate autonomy, and when does it indicate (extreme) precarity?" (Hotvedt forthcoming). Arguing that the present contract of employment test does not resolve this problem, she views the renewal of the test with updated criteria as necessary. Currently, the individual perspective forms the basis for assessment in such cases. However, since there is often great variation in the individual situations of those working via the same platform, a proper judgment of the actual power and dependency relationships requires that the business model of the platform be taken into account. A central question in this context is, To what extent does the platform have direct or indirect control over prices and pay, customer terms, work performance through the rating system, or other management capabilities? For example, if the platform discretely can choose to exclude providers who get a low rating from customers, this is a clear indication of an employee relationship, according to Hotvedt (forthcoming).

\footnotetext{
${ }^{17}$ http://www.lo.no/PageFiles/24604/delingsokonomibrev.pdf
} 


$\begin{array}{ll}\text { Source } & \text { Labour law responses } \\ \text { Eriksson (2017) } & \begin{array}{l}\text { Fragmentation of work environment responsibilities in the context of multilateral work } \\ \text { relations indicates a need for legal clarification. }\end{array} \\ \text { Prassl (2017) } & \begin{array}{l}\text { A third category of employment is not necessarily the best option as there is great } \\ \text { heterogeneity among platform workers. Ratings and reviews should be portable from } \\ \text { one platform to another. }\end{array} \\ \text { Gabrielsen (2017) } & \begin{array}{l}\text { The problem is not the law but the enforcement of it, suggesting that improved } \\ \text { enforcement by the courts is key. }\end{array} \\ \text { Comment by } & \begin{array}{l}\text { The very low number of cases in similar areas (temporary work, agency work) indicates } \\ \text { that uneven resources and asymmetric power relations prevent effective and adequate } \\ \text { enforcement via the courts. }\end{array} \\ \text { Hotvedt (2017) } & \begin{array}{l}\text { Renew the "contract of employment test" and establish a low-threshold public } \\ \text { nemnd/agency assigned to handle such cases at the pre-judicial stage. }\end{array} \\ \text { Ilsøe (2017a, 2017b) } & \begin{array}{l}\text { Adjustment of benefits, pensions, and training systems, as illustrated in new, all- } \\ \text { inclusive pension schemes negotiated in some Danish sectors. }\end{array}\end{array}$

Regarding changes in the working environment, Kurt Eriksson (2017) highlighted that the growing complexity and volume of multilateral workplace relationships, including platform work, make it increasingly unclear who is responsible for work environment issues at worksites and entails a risk of a deteriorating organizational and social work environment (SOU, 2017: 24). The Nordic Working Environment Act builds on the precondition that there is a workplace, where the employer is responsible for a healthy and safe work environment. In Sweden, there has been an increase of actors, not only platform workers, performing work on behalf of others and in other capacities than that of an employee. This causes uncertainty about who is actually responsible for HES and other employer duties (Eriksson, 2017; SOU, 2017: 24). The Swedish committee was not asked to come up with proposals on how to handle these challenges, but on direct questioning, the leader of the committee, Kurt Eriksson, left little doubt that he saw a need for legislative reform aimed at redressing the problems highlighted in the report.

As pointed out in the keynote introduction by Adam Pokorny (European Commission), the social protection rights for self-employed are underdeveloped and full of gaps in most European countries (Pokorny, 2017). In May 2017, however, Denmark launched amendments in its unemployment insurance scheme that imply inclusion of self-employed persons and others in non-standard working arrangements among those eligible for support. The amended scheme relies on activities rather than on the dichotomized categorization of self-employed vs wage earners. This means that all income earned through work - be it as a self-employed or as an employee - will generate the right to unemployment benefits. The altered scheme will enter into force in July 2018 (Kvist, 2017). In her lecture, Anna Ilsøe (FAOS, Copenhagen University) also pointed to a number of new Danish sectoral agreements on pension rights making new categories of non-standard workers, including platform workers, eligible for collectively agreed occupational pension schemes (Ilsøe, 2017a; Ilsøe et al., 2017). 
Interestingly, the Norwegian sharing economy committee (NOU, 2017: 4) proposed that those working via platforms - regardless of their employee status - should be entitled to negotiate collective agreements with their platform operators. The committee did not elaborate on how such a right might legally and practically be obtained. Legally, the boundaries between collective labour law and competition law are not clear. There might be constraints in EU competition law against self-employed building cartels to fix the price of their service, although the Albany case from $2014^{18}$ suggested that freelancers' room for negotiating collectively might be wider than previously thought. Apart from the organizational and legal obstacles that would need to be overcome (Dølvik \& Jesnes, 2017), all the main Norwegian employer confederations made it clear in the ensuing hearing round, that they did not consider collective bargaining rights for platform labour as a desirable and feasible option at that time.

\section{Social partner responses to the sharing economy, digitalization, and new forms of work}

For the special conference session on social partner responses, representatives of the Confederation of Norwegian Enterprise (NHO), the Norwegian Confederation of Trade Unions (LO), the Swedish TCO-federation Unionen, and the Federation of Norwegian Professional Associations (Akademikerne) were invited to share their views.

They all emphasized their positive approach to new, digital technologies and the potentials they entailed for job growth, innovation, and renewal of present forms of work. The Director of NHO, Kristin Skogen Lund, underscored that she had an open, optimistic view of the new digital opportunities, and warned that precipitated regulatory initiatives could strangle infant companies and industries that would be needed in the future. Referring to promising developments, for instance, in digitalized health services and the printing industry, she argued that instead of regulating new actors into old frameworks a better way ahead would be to loosen up existing regulations and allow new forms of business and work to thrive "side by side" with traditional firms and industries. A basic precondition, however, is to secure that all companies comply with general rules regarding tax payments, health, and environment. Emphasizing that permanent jobs still account for 92 per cent of all jobs in Norway - mirroring the employer benefits of trustful and predictable employment relations - Skogen Lund believes that more temporary and diverse forms of work are a likely result of the new digital opportunities. On the positive side, however, such flexibility might in her view lower the threshold into the labour market. She concluded by stating that Norway cannot afford to let the new digital developments in the international economy just pass by - rather than regulating ourselves into a corner, we

\footnotetext{
${ }^{18}$ In the case C-413/13 FNV Kunsten Informatie en Media from 2014, regarding freelance substitute orchestra musicians trying to improve their working conditions through a collective agreement, the EU Court determined that collective bargaining agreements fell outside of the scope of competition law. The reasoning behind this was that the freelancers were in a comparable situation to workers and could be regarded as false self-employed.
} 
need to take positions and make bold choices to stand the test of our ability to adjust that these developments confront us with.

The leader of the Norwegian LO, Hans Christian Gabrielsen, drew on his personal experiences to explain his positive approach to new technology. Telling the audience that the manufacturing occupation of his father - a vikler (winder) at NEBB, later ABB - does not exist any longer, along with a range of other occupations and the corner video store, he emphasized that Nordic trade unions are not that concerned with the fact that occupations will continue to disappear in the future. Their prime aim and concern is that we manage to create new jobs and occupations faster than the old ones disappear. That requires omstillingstillit - restructuring trust - according to Gabrielsen, who emphasized that almost 500,000 Norwegian employees, or one in four, change job every year. Naturally, many are worried that a robot will replace their job on the shop floor. Gabrielsen recounted how, in the 1980s, he was shop steward at a plant where technological automation led to the shrinking of the workforce from 600 to 300 while production increased from 200 to 400 tonnes. That was okay, as long as all the redundant workers got new jobs elsewhere and the real wages rose. There is no natural law, however, that ensures that it will happen that way. Since increased demands for skills and education entail a risk that workers fall out of the labour market, it is essential to meet the digital restructuring with strengthened tripartite cooperation to ensure the gains in manufacturing productivity and incomes are used to develop new jobs and equip people with competencies enabling them to enter new jobs in other sectors. Norway will, for instance, need lots of workers in construction and thousands of "warm hands" in elderly care, so robots are heartily welcomed, said Gabrielsen - at least as long as they organize, he jokingly added. In this perspective, Norwegian trade unions, he made clear, are in no way ready to negotiate reductions in the price of labour and their share of added value. On the contrary, the main task ahead is to boost the value of knowledge, skills, and production, he continued, warning against business concepts built on escaping taxes and offering low pay, eroding the collective good, and wasting resources on low productive activities. In view of the "winner take all" tendency in global digitalized markets and the fact that the share of youth never gaining foothold in working life is rapidly rising, the LO leader expressed the belief that the most important move to handle the challenges ahead of us is to launch an ambitious competence reform. Having underinvested in workforce skills and training for too long, he argued, Norway urgently needs to use the tripartite cooperation to mobilize more joint resources in investment in lifelong training and retraining making the workforce ready for the future of work.

The leader of Akademikerne, Kari Sollien, agreed with the overall optimistic perspectives of her colleagues, but stressed the importance of not letting the emphasis on new opportunities allow us to weaken the foundation of rights and security that has always distinguished the Nordic model. Given that the more fluid post-industrial working life requires a balance of security and organization, she urged the organized and political actors to protect the tripartite Nordic social models and engage in joint efforts to include those entering new forms of employment. The main confederations 
in particular, she argued, need to take a fresh look at the rights of these groups when it comes to sick pay, unemployment benefits, and other social benefits.

Fredrik Söderqvist from Unionen, Sweden's largest trade union, which belongs to the white-collar confederation TCO, used his short introduction to sketch the ideas his union has put forward when it comes to reaping the benefits and ensuring proper governance of the platform economy (see Söderqvist, 2017; 2016; Dølvik \& Jesnes, 2017: 48). Given the turbulence that can occur when path-breaking new technology interacts with rapid organizational innovation, he argued that trust is a key precondition for making the transactions via new platform technology work. So far, this has largely been a marketplace in which the platform operators determine the rules, easily giving rise to self-reinforcing network effects resulting in monopolistic competition. Whether we are facing an overhyped phenomenon or the front end of a revolution, as Prassl (2017) called it, he was unsure, but all the operational difficulties of Uber might indicate that the current platform concepts fit poorly with the Nordic institutional frameworks of work. In this view, Söderqvist argued, the approach suggested by Unionen might represent a way to provide the institutional frameworks required to muster the trust, predictability, and balancing of interests needed to make mediation of labour via platforms work work better for society. In short, the proposal is that the state and the main social partners work together to develop a meta-platform or portal through which appropriate conditions, standards, and, possibly, framework agreements for platform work can be established and authorized. Inspired by the way in which the Swedish social partners secured authorization and collective regulation of agency work some fifteen years ago, such an institutional framing through selfregulation by the social partners might help provide the predictability and balancing of interests needed to ensure that the platform technology serves as a basis for social and organizational innovation in working life.

In the ensuing discussion, there seemed to be common ground for further convergence of views and approaches among the actors. In particular, it was notable how intrigued the head of the Norwegian employers was by Unionen's ideas about how to bring platform work into orderly forms by means of social partner cooperation rather than by statutory regulation. Evidently, dialogue across Nordic boundaries can enrich national debates and help bringing actors out of their habitual domestic trenches.

\section{Platform work plays into broader labour market trends}

While the initial frenzy around the labour market effects of the "platform economy" evidently has given way to more sober approaches, the dialogues at the Oslo conference all addressed the fact that platform work plays into broader trends of working life change. In particular, the impact on jobs and distribution is closely intertwined with the digitalization of traditional industries and the evolution of new forms of non-standard work and multilateral employment relationships, which are addressed in this final section. 
Firstly, the opportunities and threats digitalization entails for traditional work were the subject of a session at the Oslo conference, where the chief economists of the main Norwegian social partners ( $\mathrm{LO}$ and $\mathrm{NHO}$ ) were asked to share their thoughts about the impact of digitalization on employment and distribution of work and social outcomes. Illustrating the legacy of cooperation in the Nordic working life models, the two parties' views proved remarkably convergent. In their perspective, the longstanding tradition of collaboration between employers and trade unions in enhancing productivity - both centrally and at the workplace - had been effective in contributing to technological change, innovation, and now digitalization (Bjørnstad, 2017; Dørum, 2017). Citing the former head of IF Metall, Stefan Løfven (currently prime minister of Sweden), who recently stated that Swedish unions did not fear new technology, only old technology, both parties emphasized the importance of Nordic trade unions' engagement in development and application of new technologies. This engagement has contributed to improving work organization, participation, and productivity, which are crucial prerequisites for securing competitiveness and jobs.

In view of the emerging spectre of robots, acting as the new "job killer", both sides pointed to historical experiences with radical technological shifts, where employment in entire industries, typically agriculture, had been decimated. Often overlooked, however, was that the rising incomes generated by productivity-enhancing technology had always increased demand for products and labour in other industries, thereby contributing to growth in total employment and production. Emphasizing that the Nordic economies had benefitted from growing wealth due to technological development, the LO chief economist pointed out that the Nordic model had also ensured that wages and incomes had been distributed in a fair and sustainable manner - in his view a key to ensuring high employment (Bjørnstad, 2017). Consenting to this interpretation, the $\mathrm{NHO}$ chief economist underlined that digitalization was no novelty in Nordic economies and argued that the well-organized and highly skilled Nordic working lives are well-equipped to benefit from digitalization (Dørum, 2017). To the surprise of some of the Nordic unionists present, however, he expressed a certain concern that the "winner take all" logic of the current form of digital globalization - with its immense concentration of wealth in a few mega-corporations with very few employees - might become a threat to nation-states' capacity to collect taxes and distribute incomes fairly enough to generate sufficient labour demand and employment. Prioritizing the modernization of tax systems and transnational cooperation on tax policy is, in his view, key to countering this risk.

Despite their basically optimistic view of the opportunities for Nordic working life in the era of digitalization, both parties left no doubt that the accelerating pace of restructuring ahead of us will require great efforts to improve the systems for skill upgrading, lifelong learning, retraining, and basic vocational education. This could sound as a joint warning that if the Nordic governments and social partners fail to match this challenge - namely to enable the workforce to become fit for new and changing tasks - there is an imminent risk that more people will fall out of work or will have to compete for the non-standard, lower-paid jobs that might or might not become available. If so, new cleavages between digital winners and losers may open up. 
Secondly, how platform work feeds into broader trends of new and often nonstandard forms of work was an issue that formed part of all the discussions at the conference. A core point in Jeremiah Prassl's keynote lecture was the immense heterogeneity of the platform economy, both regarding the business concepts of the evolving platforms and the contractual relations and working conditions of the various social groups that seek work via platforms (Prassl, 2017). There is great diversity in how the platforms are organized, the services and tasks they intermediate, the extent to which algorithms are steering the distribution and governance of work, and the remuneration, conditions, autonomy/dependence and motivations marking the situation of those working via platforms. While some are high-skilled experts with considerable market power and autonomy to negotiate the terms of their assignments, many crowd workers are left to bid for low-skilled mini-tasks associated with meagre remuneration, minimal autonomy in conducting the work, and little or no influence on their contractual terms. While acknowledging platform technology's potential for developing new, innovative forms of collaboration, networking and organization of cooperative producer communities, there seemed to be little doubt among the conference participants that the nature of job tasks and business concepts promoted by most platform companies thus far predominantly tends to propel new forms of nonstandard and often precarious employment relationships. Standard employment contracts based on open-ended management-employee relations are still dominant in the Nordic labour markets, and the share of conventional non-standard contracts typically temporary work and agency work, often of short-term character - also appears relatively stable. It seems, however, that new forms of atypical work such as zero-hour contracts, quasi-independent work, and the like have been on the rise in parts of the Nordic labour markets since the financial crisis (Ilsøe et al., 2017).

Platform work clearly feeds into the growing variety of non-standard work contracts, but as traditional labour market statistics (LFS) are not designed to single out such new forms of work, little is yet known about how this kind of work is developing. Nor do we know to what extent these are only transitional positions for those holding them, and whether people choose such work voluntarily or mainly out of necessity, for instance because of a lack of alternative job offers. Non-standard forms of work are not necessarily precarious work, understood as insecure work with poor working conditions, remuneration, and mobility prospects (Broughton et al., 2016). Still, some gig workers might risk entering a "revolving door" process of successive, short nonstandard jobs with low pay, also entailing the risk of not being entitled to unemployment benefits or other entitlements related to the wage-earner status (Pokorny, 2017). Labour in such fluid jobs has also proven very hard for trade unions to organize, even in the Nordic countries. In Finland, the incidence of self-employed without employees seems relatively higher than in the other Nordic countries, about 6 per cent of the working age population. A recent study by the Finnish Bureau of Statistics examined whether work as a self-employed person without employees was necessity-based or opportunity-driven. The results indicated a mix, but about 20 per cent of this kind of work was considered necessity-based (Pärnanen \& Sutela, 2014). Given that digitalization of traditional production and the supply of platform-mediated 
labour enhance the possibilities for externalization, and possibly auctioning, of routine job tasks and standardized assignments, more knowledge is clearly needed as regards traditional employers' adoption and use of platform technology. The same pertains to the motivation, situation, and working conditions of those preferring or being bound to accept such new forms of non-standard work arrangements.

These kind of questions regarding the impact of digitalization and new forms of work, including platform work, will feature centrally in a new four-year Nordic project procured by the Nordic Council of Ministers, entitled The Future of Work: Opportunities and challenges for the Nordic models. ${ }^{19}$ Organized by Fafo and bringing together researchers from all the Nordic countries, the project's aim is to explore how digitalization and new forms of employment might influence work in the Nordic countries in the coming decades. In line with the lessons from the Oslo conference, the project will study how digitalization and robotization of traditional industries alongside the rise in platform and new non-standard forms of work will affect employment, skill needs, working conditions, HES, labour relations, and the functioning of the Nordic labour markets. Further, the project will entail three more policy-oriented, crosssectional studies analyzing emerging needs for renewal of the Nordic model of labour market governance and Nordic policy approaches in the areas of occupational health and labour law in particular. 



\section{Part 2 - Nordic labour markets and the sharing economy - report from a pilot project}





\section{Preface - part 2}

This report is the product of a pilot project funded by a grant of DKK 250,000 from the Labour Market Committee of the Nordic Council of Ministers. This support enabled Fafo to invite a group of researchers from the Nordic countries to prepare brief national background reports and take part in a two day workshop in Oslo, 26-27 September 2016. By taking stock of available knowledge and research about work in the Nordic sharing economies and the approaches that governments and organizations adopt to influence the platform labour markets' further development, the aim was to facilitate information exchange and provide a better knowledge base for developing future Nordic studies in this area. The Nordic research group has consisted of Antti Saloniemi (University of Tampere), Per Kongshøj Madsen and Stine Rasmussen (CARMA, Aalborg University), and Anna Ilsøe (FAOS/University of Copenhagen), Bertil Rolandsson, Jesper Peterson, and Tomas Berglund (University of Gothenburg), Katrín Ólafsdóttir (Reykjavik University School of Business), and Jon Erik Dølvik and Kristin Jesnes (Fafo, Oslo). Each national team received a fee of DKK 12,000 for their contributions to the study. As explained in the national background reports, there was at the time of writing great variation in the availability of research based knowledge about the labour market implications of the sharing economy in the Nordic countries. The researchers got the opportunity to update the country reports before November 2016. There might therefore be recent policy developments in this area that are not covered in these reports. The national background reports (Nordic Working Papers, 2017: 904) can be downloaded at http://dx.doi.org/10.6027/NA2017-904 



\section{Summary - part 2}

This report presents a preliminary knowledge status about implications of the sharing economy for labour markets and employment relations in the Nordic countries. It also reviews how the Nordic countries and their social partners approach the sharing economy and issues relating, amongst other, to its legality, regulation, taxation, and terms of competition. There is so far scant supply of statistics, data and research in this field. Clearly, work via sharing economy platforms is still marginal in the Nordic labour markets, but if it gains momentum it may challenge traditional features of the Nordic labour and welfare regimes organized around the wage-earner relationship. The employment potentials and consequences of the sharing economy will, amongst other, depend on the governments' and the organized actors' responses to these challenges. Currently, all the actors seem to be in a phase of knowledge gathering and deliberation of possible policy options, cautiously avoiding taking steps that might obstruct the development of the sharing economy. In this respect, the evolution of the sharing economy and its labour market implications offers a unique opportunity to trace processes of change and policy formation in a core area of the Nordic models. The report thus concludes by pointing to knowledge gaps and themes for further follow-up studies. 



\section{Background and context: What is the sharing economy and how can it be governed?}

\subsection{How to denominate and define the sharing economy?}

There is, so far, little consensus on how to denominate and define the term sharing economy (Sundararajan 2016: 27; Kalleberg \& Dunn, 2016: 2). Other umbrella terms, such as collaborative consumption (Botsman, 2013), collaborative economy (EU Commission, 2016), intermediary economy (Jesnes \& Nesheim, 2015a) the gig economy, platform economy, crowd-based capitalism (Sundararajan, 2016) and ondemand economy (Stefano, 2016), are also used to conceptualize it. Various actors, especially the trade unions, have been critical to the term sharing economy because of its unequivocally positive connotations, the great diversity of companies referred to as sharing economy platforms, and many also argue that it is not about sharing at all. Several Nordic trade unions such as the Swedish Unionen and the Danish Confederation of Trade Unions have chosen to use the concept "platform economy" (Unionen/Söderqvist, 2016; LO 2016a). Referring to the digital tools applied in the transactions, the platform economy concept invites a more balanced or even critical assessment of it, according to these unions (Rolandsson et al., 2016; Rasmussen \& Kongshøj Madsen, 2016). In lack of a better term, the Norwegian LO has chosen to use the term "samhandlingsøkonomien" - corresponding to the term "collaborative economy", which the EU also uses (LO, 2016b; EU Commission, 2016).

The sharing economy is sometimes described as a phenomenon whereby new digital technology will revolutionize working life. Yet, neither the technology used nor the ways of working in the sharing economy are entirely new. Historically, the emergence of technology-based and collaborative work was associated with knowledge-intensive tasks. For instance, open source communities, using platform technology for parsing up and distributing tasks in a "virtual cloud" of collaborative actors started to take shape already during the early 1990 (or even before) (Ljungberg, 2000). In many instances, activities on these platforms did then also draw on complex combinations of sharing and business practices (Demil \& Lecqoq, 2006). Recent spread of concepts like crowd sourcing and distributed innovation further reflects how this kind of open source inspired use of digital platforms have become common, both in conventional software firms and other businesses within e.g. pharmaceuticals and media production (Lakhani \& Panetta, 2007; Rolandsson et al., 2011).

Leaving the debate about how to denominate the phenomenon aside, the great variations among sharing economy platforms also fuel confusion about what the 
phenomenon really is. For our purpose, an important distinction is between platforms intermediating some form of labour, and those mainly facilitating sharing or renting of assets such as homes and cars (Andreassen, 2016). The platforms that involve labour can again be divided into platforms whereby the product can be submitted online, sometimes referred to as crowdsourcing, and platforms that involve manual and local labour, sometimes referred to as on-demand work (Stefano, 2016). Another way to differentiate between platforms is by looking at what actors are involved on the customer and the provider side (individuals or companies). Platforms that facilitate exchange between persons are often referred to as peer to peer $\left(\mathrm{P}_{2} \mathrm{P}\right)$ and platforms where companies are involved are either referred to as $\mathrm{B}_{2} \mathrm{C}$ (business to customer) or $\mathrm{B} 2 \mathrm{~B}$ (business to business) (Botsman, 2013). Yet another important distinction is between profit and non-profit platforms. Couchsurfing, where you can sleep on someone else's coach is a good example of a not-for-profit platform, while Uber is typically a profit-driven platform. Such variations in emphasis reflect that the phenomenon is still in evolution, and that it is in no way homogenous.

In light of the ambiguities of the sharing economy concept, government authorities, organizations, researchers, and international agencies emphasize different traits and characteristics of the phenomenon; it is, amongst other, said to be about new digital technology, renting instead of owning, two-sided markets, networking, transaction costs, sustainability, and trust. Another significant feature is that the platforms' marginal costs per transaction are almost independent of scale, implying that the first movers can often conquer a dominant or monopolistic market position engendering a "winner takes all" logic (Degryse, 2016). Economists (Krokan, 2015; Iversen et al., 2016) tend to view the sharing economy as two-sided markets defined as "markets in which one or several platforms enable interactions between end-users, and try to get the two (or multiple) sides 'on-board' by appropriately charging each side" (Rochet \& Tirole, 2006, in Krokan, 2015). According to strict interpretations of such an approach, platforms entering into relations with the labour providers that entail an employment contract are almost by definition not part of the sharing economy. For labour lawyers and sociologists of work, who are interested in the judicial, institutional, and social implications of the new patterns of work that arise from platforms that engage with labour, such an (almost circular) interpretation of the sharing economy concept is too narrow to be helpful in understanding the variegated and blurred implications of the platform companies' labour practices.

Our conceptualization of the sharing economy takes the role of the digital platforms in intermediating between providers and consumers as a starting point, and builds on the three elements of the sharing economy described by Jesnes and Nesheim (2015b):

1. an intermediary company in the form of a digital platform, which helps to

2. connect providers and consumers/clients, to

3. perform transactions, such as services, sharing of assets/property, skills or labour. 
For those platforms involving labour, which is the main focus of this report, a triangular relationship is formed between the platform company, those who provide labour, and those who purchase labour services. Jesnes et al. (2016a) emphasize the variety of such triangular relationships, especially with respect to the elements pointing in direction of an employment relationship. It should be kept in mind that such triangular employment relationships are not novel, as illustrated for example by temporary agency work and the consultancy business (Evju, 2012). Although Jesnes \& Nesheim's conceptualization does not make a clear-cut distinction between pre-existing triangular relationships and new digitalized forms of such relationships, it is a starting point for exploring how the ties between these platforms and their workforces differ from other triangular employment relationships.

As indicated, the so-called sharing economy is a fuzzy concept that is hard to define and far from everything about it is new. Yet, in view of its transformative potentials, the ways and mechanisms by which app-based platform companies match demanders and suppliers of work and resources definitely deserves further scrutiny.

\subsection{What are the concerns and interests of the governments and the social partners?}

The sharing economy was first put on the public agenda in the Nordic countries late 2014, when Uber entered the Nordic markets. Since then, government authorities, politicians, social partners, academics and other actors have engaged in the public debate about the opportunities and challenges associated with the sharing economy and how it ought to be governed. The public debate has typically covered a wide range of issues. Yet in Iceland the debate has mostly been concerned with Airbnb which has helped to facilitate the tremendous growth in the tourism business there (Ólafsdóttir, 2016), and in Finland, the debate has so far mostly been concerned with Uber (Saloniemi, 2016). In both countries, however, the environmental and consumer aspects of the sharing economy have been lively discussed.

Since 2014, the sharing economy has evolved, and there is now a mushrooming plethora of Nordic start-ups operating under the umbrella of the sharing economy term, especially in Denmark, Sweden and Norway. The issues of controversy include the risk of tax evasion, distortion of competition, erosion of employment relationships, and broader societal interests concerning consumer protection, control/supervision of workers, and data security. Uber is the company that has generated the most public debate in the Nordic countries. This is primarily because it refuses to comply with existing transport regulation as it defines itself as a technology company, but also because it claims that the drivers are self-employed and not working for Uber.

Governments in the Nordic countries are positive to the sharing economies' potential for generating growth, innovation, and job opportunities, but they also recognize the challenges arising in particular with regard to maintaining a level playing field and sound, fair taxation of different categories of companies. At the moment, they seem to be in a learning and deliberation process, where they collect information and 
prepare the basis for policy proposals and approaches through various commissions and green/white papers on issues related to digitalization and the sharing economy. ${ }^{20}$

The social partners, especially the trade unions, have engaged actively in the debate about the sharing economy in the Nordic countries. For instance, Unionen in Sweden and the LOs in Denmark and Norway have issued position papers on the sharing economy, where they acknowledge the importance of technological development and innovation, but also voice their concerns about casualization of work, protection of labour rights, health and safety, and risk factors related to surveillance, taxation, and social security (Unionen/Söderqvist, 2016; LO, 2016a; LO, 2016b). Surveys among trade union representatives in Denmark and Norway reveal that a majority believes that the sharing economy will undermine labour rights and lead to unfair competition and tax evasion (LO, 2016a; LO, 2016b; Redder, 2016; Ødegård, 2016). Although many trade unions are critical to the term "sharing economy", the largest white-collar federation in Sweden, Unionen, has adopted a set of visions for how the platform economy can be incorporated into the Nordic model (Unionen/Söderqvist, 2016). Some unions have taken initiatives to recruit freelancers, and others have voiced ideas about framework agreements with employers as well as provision of social security for freelancers either through union-organized funds or political channels. The employers' and business organizations mainly seem to have adopted a "light touch" approach towards the issue, embracing its potential for growth, innovation and job creation, but due to alleged distortions of competition some tension has occurred between organizations representing "old" and "new" industries.

\subsection{The risk of tax evasion}

Taxation seems to be the issue of most concern in the Nordic public debates about the sharing economy. Firstly, many actors, including trade unions, are worried about the entrance in the Nordic services and labour markets of several international companies that are not established in the Nordic host country but registered in tax havens and therefore allegedly not obliged to pay taxes in the Nordic countries. In this way, the international organization of major companies in the sharing economy might reduce tax revenues. Besides the platform companies' free access to capital equipment and other assets owned by the users, this may give the platforms established offshore a competitive advantage vis-a-vis domestic companies that normally have to pay corporate and pay-roll taxes as well as, in most instances, indirect taxes (VAT).

\footnotetext{
${ }^{20}$ See e.g. Fellman, 2015: 65, SOU, 2015: 91, NOU, 2017 (forthcoming), and Regeringen (2016:37-38), where the former Danish Government announced that an elaborate strategy for the sharing economy will be published soon. The new Danish Government, which took office on November 28, announced in its government platform that it will set up a Disruption Council including the social partners, companies, experts, and relevant ministers, to discuss and analyze the labour market of the future.
} 
Secondly, the platform companies normally leave it up to the individual users of the platform to report taxable incomes and activities. ${ }^{21}$ Tax administrations are concerned about how to identify and control that individual users - such as Uber drivers or property owners renting out through Airbnb - pay taxes on their incomes and transactions in the sharing economy without third party reporting. Platforms typically have payment systems and data on all transactions performed through their platform and could report this to the authorities, although there might be some issues related to ownership of data and privacy protection. Yet, the governments have not yet demanded the companies to report on what the individual drivers earn. Altogether, proper resolution of the tax issues is thus important both to secure public revenues and to facilitate a level playing field.

\subsection{Distortion of competition: How to maintain a level playing field?}

Another issue of concern, often evoked in the public debate, is how to secure a level playing field between traditional firms and the platform companies. The case of Uber illustrates the problem. Uber offers several services, among which UberPOP is the most controversial as it enables individuals to use their own cars and drive unlicensed against a fee to Uber. The fee is set at between 20 and 30 percent of the price for the "ride", which both are unilaterally determined by Uber. Apart from the guaranteed net profit for each ride, Uber benefits from a significant competitive advantage compared to traditional taxi companies, as all capital costs, maintenance, and expenditure on fuel etc. are transferred onto the "drivers". Airbnb enjoys a similar competitive edge vis-àvis ordinary companies in the hospitality sector since the capital and equipment costs of the flats/rooms from which it derives its profits are covered by the client asset owners. In addition comes potential cost advantages of not taking on any employer or pay-roll tax responsibilities for the work conducted in relation to the services.

The legality of UberPOP's operations is contested, also in the Nordic countries and at the EU level. The basic question is whether or not Uber should be considered as a technology company, which the company claims, or a transportation (taxi) company. ${ }^{22}$ If Uber's activities are considered to be similar to that of a taxi company, ${ }_{1}^{23}$ it would most likely be subject to payment of corporate taxes, pay-roll taxes for employed drivers, and VAT in the country it operates, while the drivers would be obliged to obtain licenses,

\footnotetext{
${ }^{21}$ As an exception to this observation the Danish tax authorities in September 2016 received information about the income of Uber-drivers operating in Denmark. The information was given by the Dutch tax authorities, who had access to them through the Dutch Uber-company administering the payments of Uber-drivers in Europe.

${ }^{22}$ This issue is at the time writing being tried in the European Union Court of Justice, where a group of Spanish taxi-drivers has claimed that Uber's operation there is in conflict with Spanish transport regulations. ESA, the surveillence authority in EEA, supported Uber in this case, and has recently challenged Norwegian taxi regulation of being in breech with the freedom of establishment in EU/EEA (Klassekampen 07.12.2016).

23 In recent court cases in London (Employment Tribunal, Case nos: 2202551/2015 \& Others) and in North California District Court (Case 3: 13-cv-03426oEMC, 11 March 2015), the courts "resoundingly rejected the company" s [Uber] assertion that it was a technology company and not in the business of providing transport services" (cited from p. 17 of the London Employment Tribunal).
} 
registered cars, taxi meters, and to pay income tax, social security levies etc. Uber started its UberPOP activity in the capitals of all the Nordic countries, except Iceland, in late 2014 (see Jesnes \& Dølvik, 2016; Ólafsdóttir, 2016; Rolandsson et al., 2016; Rasmussen \& Kongshøj Madsen, 2016; Saloniemi, 2016). From its launch, Uber's legal status in Finland was unclear until autumn 2016, when the Court of Appeal stated that driving for Uber contravenes Finnish legislation (Saloniemi, 2016). Occurring almost simultaneously with the legal resolution, a political struggle over deregulation of the transport sector came to its conclusion. The new regulation loosens permit conditions for taxi driving - except requiring command of Finnish language - but does not take full effect until 2018 (ibid, 2016). In Sweden, the police has conducted several investigations on whether or not the Uber drivers' activity can be considered as car-pooling or as taxi service. In May 2016, Uber stopped its activities in Sweden as a result of repeated judgements in the Swedish legal system establishing that driving for Uber is the same as participating in a pirate taxi operation and several drivers have been sentenced for tax evasion (Dagens Næringsliv, 11.05.2016).

UberPOP is also considered illegal in Denmark and Norway. In Denmark, six Uber drivers were convicted of violating the taxi legislation by the municipal court in Copenhagen and convicted to pay a fine. The sentence was appealed to the "High Court", and was confirmed late 2016. More legal proceedings against Uber drivers are on the way, but Uber is still operating in Copenhagen (Politiken, 30.09.2016). In Norway, more than 70 Uber drivers have been stopped by the police and suspected of illegal taxi operation, and the police has taken legal action against two drivers who had acted as Uber chauffeurs on a regular basis. Recently they were found guilty of breaching transport legislation by being involved in professional transport services without the required licence. The police has started to temporarily withdraw driving licenses from Uber drivers (Aftenposten, 20.10.2016). In a recent court case a number of drivers lost their driving licenses and had to pay fines and cede their earnings from Uber driving (Aftenposten, 16.12 2016), Still pending in the Nordic countries, however, is an ultimate judicial decision clarifying whether, and the conditions under which, the drivers can be considered employed by Uber and thus entitled to protection, amongst other, by national labour law.

The case of Uber illustrates how the sharing economy can disrupt the terms of competition in disfavor of ordinary companies with employed staff. The risk of unfair competition has been warned against both by employer organizations and trade unions as well as in international literature discussing the conditions for sound development of the sharing economy. Einav et al. (2015) thus argue that peer-to-peer markets must be designed so that the actors compete on equal terms with respect to insurance and security. Harris \& Kreuger (2015) take the argument further and maintain that in order to reap the innovative potentials of the sharing economy the need for neutral competitive conditions should even include social conditions such as pay and conditions: "[l]f an intermediary actor (platform) outcompetes traditional employers that supply the same services because the intermediary actor reaps cost advantages by avoiding provision of certain legally guaranteed benefits and protections, the total welfare will be reduced by this innovation." (Harris \& Kreuger, 2015, cited in Unionen/Söderqvist, 2016: 93, translated by authors.). 
According to Rasmussen \& Kongshøj Madsen (2016), some of the strongest criticism of the sharing economy in Denmark has been raised by employer organization's representing businesses directly affected by the large platform operators, such as Uber and Airbnb. Hence, Dansk Taxi Råd (Danish Taxi Council), organizing the majority of taxi companies, has criticized the activities of Uber, and at the same time called for a modernization and liberalization of the complicated regulations of the taxi trade. Its main claim is that a level playing field should be created, where platform based services will compete with other transport providers on equal footing. Together with other employers organizations involved in the taxi business, a proposal for reform was sent to the Minister of Transportation in October 2015 (Dansk Taxi Råd et al., 2015). Similar arguments have been raised by employer associations in the taxi industry and the hospitality industry in other Nordic countries. Yet, apart from the employer and business associations in directly affected industries, it seems that the main employer umbrella associations in the Nordic countries have adopted a laid-back approach to the issue. The same pertains to organizations representing potential users of platform services and those representing the platforms themselves. For example in Norway, the NHO-affiliated Abelia organizing technology companies - including about ten sharing economy platforms - in late 2015 , lobbied actively on behalf of the platforms, among others by setting up round tables with representatives of the platforms, the Finance Minister, and the Director of the Tax Administration. This was part of the background for the Norwegian government's appointment of a sharing economy commission in 2016. In general, it seems as though governments in the Nordic countries work on balancing the need for a level playing field and the desire not to compromise the potential of the sharing economy in creating growth and innovation.

\subsection{Changing employment relationships?}

Prophecies that the traditional standard employment relationship is waning are not new. They have been with us since the data revolution and the quest for employment flexibility and liberalization in the 1980 sparked concern about jobless growth, atypical work, and flight into the 2/3rd society. These predictions proved to be skewed, however, especially in the Nordic countries where growth in regular jobs recovered fast from the 1990 and the vast majority is still in open ended, standard jobs. Yet, there are factors that may suggest that "this time is different". In a context of international secular stagnation and high unemployment (Summers 2016), one cannot preclude that the pace of change in production and communication technology, world-wide sourcing, cross-border mobility, and instant, digital linking of end users, intermediary firms, and people searching for jobs will engender profound changes in the pattern of work and employment relations in parts of the labour market.

The sharing economy is marked by proliferation of triangular relationships between the platform companies, those who provide labour, and those who buy labour services (Sundararajan, 2016). Although triangular employment relationships have existed for long, what is new is that both the platform intermediators and the 
customers or client companies relate to those who provide work in new, digitalized and more distanced ways. Often, the relationships between platforms and providers of work in the sharing economy seem to vary from platform to platform. Looking into the employment relationships in five platform companies in Norway, Jesnes et al. (2016b) found that in their triangular arrangements they combined a variety of relations to the workforce. Most of the companies did not consider themselves as employers, yet they in many ways performed control over the workers and had long term relationship with them, aspects indicating the existence of an employer-employee relationship. Other Norwegian companies associated with the sharing economy do in fact regard themselves as employers, but they do not take on all the responsibilities that employers are required to, such as providing equipment necessary to perform the work (examples: car, bike etc.) (ibid).

These variations in employment relationships imply that it will often be difficult to determine whether those who provide work are self-employed or independent contractors, as the companies tend to claim, or whether they are workers employed by the platforms. The blurring of the boundaries between workers and self-employed has spurred a growing literature about the nature of the relationships between the platforms and their workforces (see e.g. Prassl \& Risak, 2016; Hotvedt, 2016), and has led the Swedish government to appoint an investigation assigned amongst other to assess the need for adjustments in the work environment act. ${ }^{24}$

24 http://www.sou.gov.se/utredningar/?owner=arbetsmarknadsdepartementet\&selection=pagaende A 016:01 Utredningen om arbetsmiljöregler för ett modernt arbetsliv. Särskild utredare: Kurt Eriksson. 


\section{Platform work: implications for employment relations and the broader labour market}

Historically, embracing knowledge and new technologies that have been viewed as engines for growth and renewal in the small, open Nordic economies, the organized actors in the Nordic labour regimes have been praised for their joint capacity to cope with change and shape working life developments in ways that have benefitted business as well as workers and the wider society (Dølvik et al., 2014). The Nordic labour markets have thus been renowned for their high levels of employment, organization, collective regulation, trust, and egalitarian distribution of wages and job opportunities. The vast majority of Nordic employees still have open-ended jobs and "standard employment relationships", but the shares with atypical jobs - in the form of fixed term contracts, parttime, agency work, on-call or self-employment - have showed a slight upward tendency in recent years along with growing outsourcing of work to consultants, subcontractors etc. (ibid; Andersen et al., 2014 ). While the Nordic labour markets recovered well after the crisis in the early 1990s, the years that have passed since the global financial crisis in 2008 have shown more divergent developments. Except in Sweden, the level of unemployment is higher, employment rates have declined, and wage and income inequalities have increased. These developments have come along with declining unionization rates, increased labour migration, low wage competition, and growing shares of youth struggling to gain foothold in the labour market.

With forecasts of weak, volatile international growth and prophecies that the digital "fourth, industrial revolution" will destroy traditional jobs on a potentially large scale, the prospect that the sharing economy may serve as a lever for innovative job creation and more effective matching of labour supply and demand has thus been positively received in the Nordic countries. But the promise of the sharing economy gurus and thinkers that platform work implies a "liberation" from the wage earner relationship around which the Nordic models and their working lives are built, has indeed sparked ambiguity in many circles and skepticism among those being most directly challenged by the new business concepts. At the same time we see that some of the platform companies, at least in Norway, start offering more standard contracts and seek collaboration with the social partners in providing more predictable employment relationships (Jesnes et al., 2016a). Also, recent court decisions in the US and the UK have overruled the platform companies' assertion that they have no employer responsibilities for their workforces (London Employment Tribunal, 2016; North California District Court, 2015). Still being in its infant stage and connecting workers and customers on a global scale, it is too early to draw qualified conclusions 
about how the spread of platform work will affect net job generation in the high-cost Nordic countries and how it will affect pay, working conditions, and employment relations in wider parts of the labour markets. Some might assume that the highly regulated Nordic working lives are especially vulnerable to the liberalizing - or disruptive - effects of the platform companies, while others might assume that the Nordic models with their mostly liberal product market regulations, high levels of education, and strong social partners are well equipped both to reap the innovative potentials and bring the new forms of work in the sharing economy into their institutional folds.

\subsection{The size of the Nordic platform labour market}

The unclear definitions and boundaries of the sharing economy obviously make it difficult to measure its magnitude. Also, when trying to measure the size of the sharing economy, one can adopt several perspectives, looking at the number of platforms, their economic significance, and the number of platform clients, workers or hours worked. Here we will only briefly refer to platform and consumer figures, and focus on the scant data regarding the number of people working through the platforms. In this area, there is no prior research to draw on from Iceland and Finland (Ólafsdóttir, 2016; Saloniemi, 2016), whereas a few quantitative surveys have been conducted in Denmark, Sweden and Norway. These surveys indicate that the sharing economy still is marginal in the Nordic labour markets.

When it comes to the number of platform companies, a mapping conducted in Norway ${ }^{25}$ suggests that there in November 2016 were about 30 platforms involving labour in Norway (Jesnes et al., 2016a). As the sharing economy is still evolving and platforms are established and disappear rather frequently, the numbers are likely to change fast. Jesnes et al. (2016a) also emphasize that many of the companies discussed under the heading of the sharing economy are start-up companies trying to find their desired business model. Some of these have already changed from hiring freelancers to hiring employees on open-ended contracts with few working hours.

Most of the platforms, at least in Norway, are registered as technology companies, but many of the platforms intermediate labour to individuals or companies within cleaning, hotel services, food, transport, or office-based tasks. Other platforms offer many different services. One example is "Finn.no småjobber" set up by a large, longstanding company (Finn.no), where firms or individuals can create a so-called "ploy" on the website, which is a short description of the task they want someone to do - painting, gardening, bartending and "handyman-like" tasks - and then individuals can apply for that ploy. Thereafter the client, the firm or the individual, decides whom to hire for the job. Payment takes place through the website, and after the task is completed the persons involved write a recommendation of each other. Similar

\footnotetext{
${ }_{25}$ Mapping conducted by Fafo and Center for Applied Research (SNF, Norges Handelshøyskole) as part of a project commissioned by the Ministry of Labour and Social Affairs.
} 
initiatives can be found in Denmark, under names like AHandyman.dk, Lejdet.dk, DenLilleTjeneste.dk, HappyTown.dk and Meploy (Rasmussen \& Kongshøj Madsen, 2016; Svansø, 2016). While Finn.no småjobber seems to have conquered a dominant market position in Norway boasting more than 25,000 subscribing providers or "helpers" - of which some 3,000 appear to have pursued at least one job - the Danish market is apparently more differentiated with e.g. 2,500 persons having signed up to work through Meploy in the Copenhagen area and 6,000 for AHandyman nationwide. Common for the different platform companies is that the firm behind the website takes a certain amount of money in commission for matching the workers and jobs or a fee for having a profile on the website (Rasmussen \& Kongshøj Madsen, 2016).

Reminding of the need to read figures about the proliferation of platform work critically, a Danish study showing that among the 1621 Danes that had signed up for work at Upwork only 163 had actually carried out any tasks (ibid.; CEVEA, 2015: 41). Similar numbers are found in Norway. In 2015, 7,900 freelancers were registered on Upwork in Norway, but only 100 freelancers earned money through Upwork every month, according to the CEO (Olsen, 2015). That is, only 1.3 percent of the registered Upwork freelancers in Norway got an assignment every month (Jesnes \& Dølvik, 2016).

As work in the sharing economy is often occasional and the status of the workers is unclear, it is impossible to identify and trace those working for the platform companies in the National Labour Force Surveys (LFS). Although the LFSs in some of the Nordic countries - e.g. Denmark, Sweden, and Finland - do indicate an increase in the number of self-employed without own employees and also of workers with few hours, it is too early to infer that this has been influenced by the emerging sharing economy. In the Norwegian LFS, the categories that might include some sharing economy workers (selfemployed without own employees and permanently employed with few hours) have remained stable in the past 15 years (Nergaard, 2016). The same pertains to the share of self-employed in Iceland (Ólafsdóttir, 2016). Eurostat is, however, organizing an ad hoc module in the national LFSs focusing on self-employment that will be conducted in the Nordic countries in 2017, possibly giving a better view of the developments in selfemployment and how they can be accounted for (Eurostat, 2016). ${ }^{26}$ Looking into other sources, a study by The Swedish Agency for Economical and Regional Growth (Tillväxtverket) shows that the number of companies in Sweden without employees has increased from 310,000 during 1993 to 850,000 during 2014 (Rolandsson et al., 2016). This has evidently had little to do with the sharing economy. While the number of selfemployed in Denmark has remained pretty stable - as in Norway - there is within this category a marked shift towards self-employed without employees in recent years. This occurred long before the rise of the sharing economy though, and this group has actually declined since 2013. In Sweden, also a few more limited, short-term inquiries do suggest a recent rise in self-employment, e.g. a study conducted by Egenanställningsföretagens Branschorganization, representing this sector, indicate an increase between 2012 and 2014 in the number of self-employed from 5,402 to 11,230

26 "EU labour force survey - ad hoc modules" http://ec.europa.eu/eurostat/statistics-

explained/index.php/EU_labour_force_survey_-_ad_hoc_modules 
(www.egenanställning.org). A more recent study by Novus indicates that the number of self-employed has increased further, reaching 18,000 during 2015 (Rolandsson et al., 2016), but there is to our knowledge no evidence indicating that these increases can be attributed to the sharing economy. Also in Finland there has been a rise in the number of self-employed since the 1990s, especially among men, but the main rise came long before the sharing economy (Pärnänen \& Sutela, 2013, in Saloniemi, 2016).

In Sweden and Norway, surveys of "gig-workers" have also been undertaken. In 2016, University of Hertfordshire together with Ipsos, Foundation for European Progressive Studies (FEPS), and unions like Uni-Europa and the Swedish trade union Unionen, undertook such surveys in a number for countries (Huws \& Joyce, 2016 a, b, c, d). In Sweden, the survey including 2,146 adults aged from 16 to 65 years suggested that 12 percent of the population sometimes work for online platforms such as Upwork, Skjutsgruppen, Uber, and Airbnb. 4 percent of the sample said they engage in this type of work at least once a month, while only 3 percent of the men and 2 percent of the women reportedly engaged on a weekly basis (Huws \& Joyce, 2016a). Without information about how long and how frequently per month or week the respondents usually work, this tells little about the volume of work laid down apart from indicating that it is on a fairly occasional basis. Yet, in terms of headcount it seems that more people are involved per week than in e.g the temporary agency industry in Sweden which employs less than 2 percent of the workforce (Unionen/Söderqvist, 2016). By comparison, conservative estimates from the US suggest that between 0.4 and 1.0 percent of the US workforce perform contingent work through digital market places (Harris \& Kreuger, 2015: 12). ${ }^{27}$ In Norway, Fafo and SNF, commissioned by the Labour and Social Ministry, have conducted a survey similar to the Hertfordshire study (Jesnes et al., 2016a). In the survey including 1,525 adults aged 18 and above, 10 percent answered that they sometimes work for online platforms. 2 percent of the respondents performed platform work on a weekly basis, 1 percent on a monthly basis, and 6 percent at least once during the last year. Having interviewed platform companies giving much lower estimates of gig-workers connected to their platforms, the researchers warn against taking these figures too literally (ibid). The survey will be reproduced by Fafo in 2017. FAOS will also, in 2017, as part of the LFS conduct a similar study attempting to measure how many work in the sharing economy in Denmark.

In the other Nordic countries there have been no such studies of how many that work through the sharing economy. Yet, in Denmark a study by Gallup conducted late 2015 asked an online panel if the respondents had participated in the sharing economy (as consumers) during the last 6 months (Rasmussen \& Kongshøj Madsen, 2016). Here, the

\footnotetext{
${ }^{27}$ Harris \& Kreuger (2015: 12) judge that "[l]f the number of workers providing services through an intermediary is proportional to the number of Google searches - an assumption that is quite plausible for Lyft and less clear for other intermediaries - then there would only be about 600,000 workers, or 0.4 percent of total employment in the United States, engaged with all of the intermediaries in the Appendix table. If, however, Google searches translate into five to ten times as many workers per search incident for apps other than Uber and Lyft-to make an extreme assumption-then there would be about 1.2 to 1.9 million workers engaged in the online gig economy. This figure is in the ballpark of McKinsey's estimate that 1 percent of the U.S. working-age population participates in 'contingent work that is transacted on a digital marketplace (McKinsey Global Institute 2015)."
} 
sharing economy was exemplified as the use of Airbnb, Uber, GoMore (car-pooling) or Resecond (exchange of dresses). Of the respondents, 9 percent answered yes. A year earlier the share was 3 percent. The study showed that young people and people with residence in the capital were most likely to utilize the sharing economy, and that the rates of participation were highest in the lowest and highest income groups. Not distinguishing between different user activities, the survey did not allow for identifying activities involving paid work. The total turnover in the activities measured in the survey was almost DKK 1.2 billion and the total number of participants estimated to 315,000 persons (Erichsen, 2015; Nordea, 2016, in Rasmussen \& Kongshøj Madsen, 2016). Another survey from Denmark, conducted by Dansk Erhverv (the Confederation of Danish Enterprise), showed very similar results with a user rate of 10 percent. While 5 percent had used Uber or similar services and 8 percent had used Airbnb or similar services, the study also showed that sharing economy services were often used when travelling abroad (Munkøe et al., 2015). According to a similar study of utilization of sharing economy services in Norway 2016, 6 percent of the (adult) population considered themselves as active users of sharing economy platforms (Slettemeås \& Kjørstad, 2016).

Seen together, the surveys indicate that the sharing economy still is fairly marginal in the Nordic countries both with respect to its penetration into the consumer markets and as a channel for providing work. Yet, given its recent emergence the studies do indicate that the sharing economy has been spreading pretty fast also in the Nordic countries. Whether and how long that will continue remains to be seen, however, especially when it comes to its ability to attract people searching for work.

\subsection{Challenging the Nordic working life model?}

As indicated above, the business concepts marketed by prominent platform companies, most conspicuously illustrated by Uber, are challenging defining features of the Nordic working life model built around the wage earner relationship. Contrary to the standard work contract where the employer is legally obliged to take on broad and lasting responsibilities for its employees, many of the pioneer platform companies have denied any such responsibility and asserted that they - as pure technology providers only connect and facilitate exchange of labour between user clients and independent contractors (or freelancers). This implies that the basic contractual relation determining the terms and conditions for work is between the purchasers and the independent suppliers of labour services (Jesnes et al., 2016a). Triangular work arrangements are well-known in the Nordic models. For instance in Sweden, the conditions for temporary agency work are determined by sectoral collective agreements and the workers have regular employee contracts with their agency (Håkansson et al., 2013). However, triangular arrangements where the intermediary, defining and controlling the terms and way of work, refuses any responsibility for the people who actually produce the services, represent a new twist that is likely to reshape the relations of power and economic exchange in disfavour of the weaker part, i.e. the workers. If such forms of triangular work should gain momentum and out-compete firms and workers 
"burdened" by the costs and constraints of the wage earner relationship on a large scale, it could indeed pave the way for a casualization of the labour market and erosion of its institutions that have hitherto been unseen in the Nordic countries. Yet, as earlier underscored, the digital platform industry is still in its early stage, and the dynamics evolving on the ground appear to be considerably more variegated and contradictory than the idealized visions of liberalization and flexibility that many platform entrepreneurs have branded. As with most new phenomena in the world of work, time is needed to see how the industry evolves when it matures and is faced with the strategic responses of other stakeholders, the social partners, politicians, courts, and the wider society. In this section, we sketch some observations from early studies of the traits marking employment relations and working conditions in the labour oriented segment of the sharing economy, and point to some of the dilemmas that the actors of the industry and its interlocutors will have to grapple with in the years to come.

\subsubsection{Changing employment relationships}

Many observers emphasize that the sharing economy builds on a business model where private persons, by means of digital platforms, agree to provide services or hire property and assets from each other (see f.ex Juel, 2016; Iversen et al., 2016; Krokan, 2015). This "peer-to-peer" or two-sided market understanding tends to underestimate the pivotal role of the platforms in structuring the terms and framing of the relations, especially when it comes to exchange of paid labour (Jesnes et al., 2016a). Recalling the conceptualization of the sharing economy developed in Jesnes \& Nesheim (2015b), the role of the platforms is crucial and constitutive for the character of the evolving triangular relationships. Not only do they connect suppliers and customers with complementary interests, they also shape the conditions under which the exchange of labour and its products take place, and determine unilaterally the revenue that befalls the platform as result of the exchange between the other parties. There is thus normally no sharing of the value added that the workers contribute to, neither of the risk of remaining without work and income in the market for assignments. Hence, rather than sharing, the striking trait of the new business models is the platform's twofold role in intermediating and structuring the relationship and division of benefits and risks between the other stakeholders, thereby potentially enabling it to become the supreme, principal agent in the processes of triangular exchange and interdependency (see figure 1). In such a configuration, the two-way relations are inherently prone to asymmetries whereby the weaker part risks becoming subject to subordination and unequal exchange. The seducing notion of sharing has served to obscure these risks, but as the sharing economy has become subject to closer scrutiny in courts and research, this aspect has indeed become harder to ignore. 


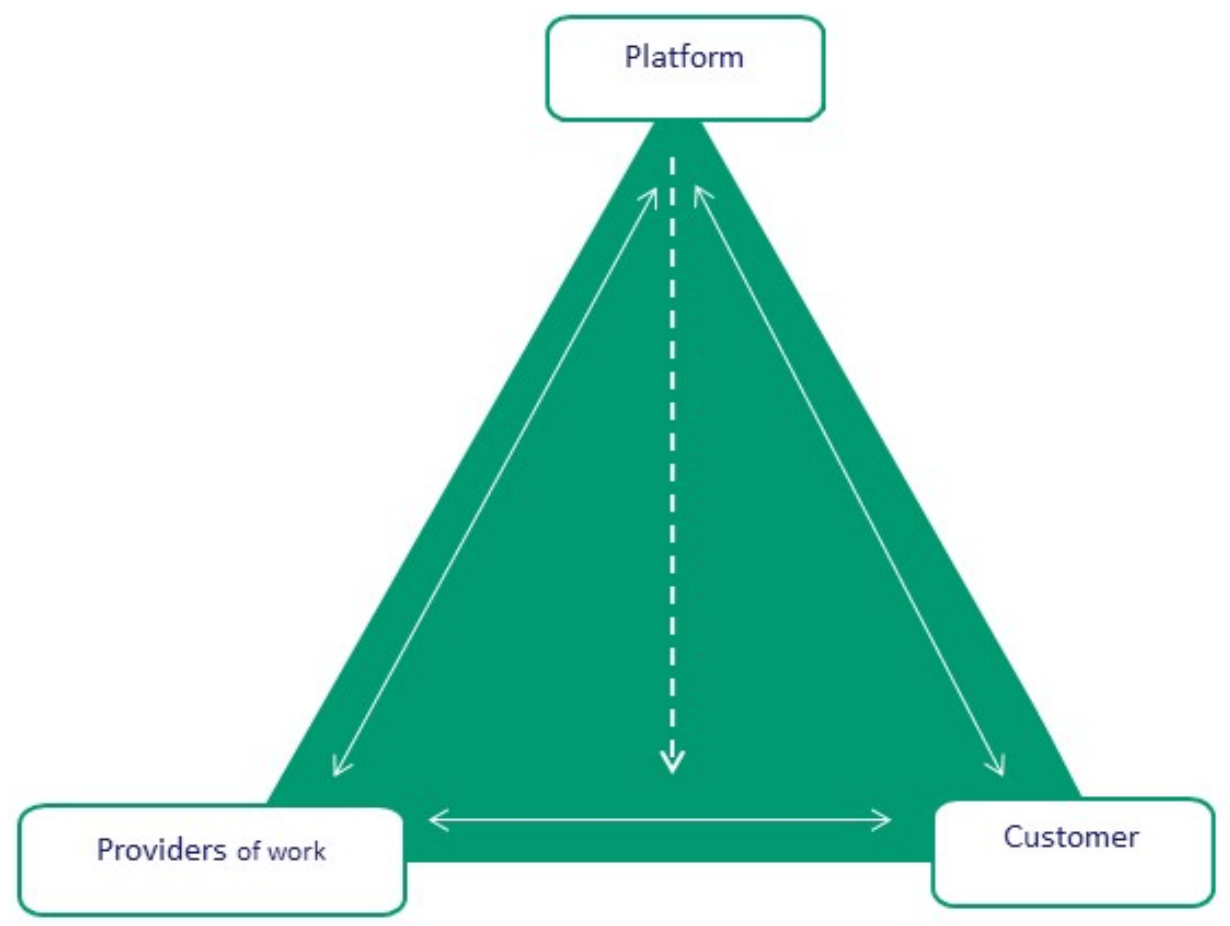

Source: Jesnes \& Nesheim, 2015b.

The relations between the platform and the provider of work, between the customer and the provider of work, and between the platform and the customers can be of varying character. In the following we leave aside situations where the platforms merely broker contracts between enterprises buying and selling different products (B2B), which are basically akin to digital trade between conventional companies. Focus is thus on situations where the platforms facilitate exchange of labour between individual workers and customers. The latter can comprise companies ( $\left.B_{2} C\right)$ or individual consumers $\left(\mathrm{P}_{2} \mathrm{P}\right)$. This understanding of what is part of the sharing economy is in line with for instance Botsman (2013).

As mentioned above, an important distinction here is between labour services that are provided online - and thus can be delivered world-wide - and labour services that are territorially bound such as car transport, child caring, gardening work, dog-walking etc. In spite that such work is often done on short-term, occasional basis - in many instances besides an ordinary job - relations resembling the traditional employer/employee relationship can evolve both between the platform and the worker, and between the customer and the worker. In earlier known triangular cases such as temp agencies, subcontracting and consultancy work, those doing the work are usually employed by the party renting out labour (Evju, 2012). In the case of platform companies, however, the digitalized routinization and rationalization of the intermediating role - in principle allowing a massive upscaling of the brokering function 
with no rise in marginal transaction costs - entail the potential to cut the ties between the company intermediating labour and the workers, in effect leaving those doing the work without any defined employer. Premised on its assumed legality, the business idea of the pioneer platforms was to do exactly this, that is, to redefine the potentially boundless volume of labour they can offer to the market into "freelancers" or "independent contractors/providers of business services" with no strings attached to the platform. As in the case of Uber, this was therefore stipulated in the contracts regulating their relations to the workers subscribing to their platforms.

However, in labour law the character of the ties between actors exchanging labour services is not up to one of the parties themselves to define or postulate by contract, but depends on the actual nature of their relationship such as the worker's actual duties and rights in the relationship, its duration, governance, form of remuneration, and its elements of subordination and dependency (Hotvedt, 2016; Prassl \& Risak, 2016). Regardless of intentions and the contract entered between the actors, such aspects of the relationship can in instances of platform work in principle make both the platform and the customer into employers, with all the legal obligations that entail in terms of pay, working conditions, job protection, taxation, insurance, social security and so forth. To maximize the economic potential of the platform technology, this is precisely what platform companies like Uber and others sought to avoid when designing their business concept; the larger the crowd of potential labour providers signing up, the larger the circle of customers they can service, given that the business idea relies on the platforms' ability to respond instantly to requests for work to be done. In this perspective, ending up with employer responsibility for all those working through the platform would represent an unforeseen constraint on the ability to expand the business. Many platforms have also sought to avoid becoming part to a "business service contract" with the individual providers of work, as that implies that the latter would in principle be free to negotiate the terms of the contract and the manner in which it should be fulfilled, again constraining the platforms' possibilities to rationalize, automatize, and control the labour suppliers' performance and delivery of the products. In the case of Uber, for example, the business idea seems premised on the assumption that there is an implied "business service contract" between the customer and the driver.

Whether the Uber drivers should be considered as self-employed or employees was recently tried in a British tribunal, whereby the tribunal ruled that the claimant drivers should be considered as "workers" which give certain employment rights including, amongst other, minimum wage, regulated working hours, and annual leave. Furthermore, Uber is obliged to pay taxes on behalf of the workers as an employer (London Employment Tribunal, 2016). ${ }^{28}$ Yet, the tribunal did not rule that the drivers

\footnotetext{
${ }^{28}$ According to the Employment Rights Act 1996, Limb (b) of section 230(3) covers an individual who has entered into or works under or worked under "any other contract... whereby the individual undertakes to do or perform personally any work or services for another party to the contract whose status is not by virtue of the contract that of a client or customer." (Press Summary, High Court, 21. May 2014, uksc-2012-0229-press-summary). Although workers falling within the Limb (b) have more limited employment rights due to nature of their position, they, in this case the drivers, are entitled to a substantial amount of employment rights derived under both EU law and UK local laws such as minimum wage, annual leave,
} 
were employed in a regular employment contract, which gives full worker rights. Although the verdict is likely to be appealed to a higher instance, it is considered to be a huge setback to Uber's business model of recruiting self-employed, and the way of reasoning in the case might have repercussions for the company in other countries.

So far, no similar cases are tried in Nordic courts. Hotvedt (2016) has analyzed Uber Norway's contract, concluding that the contract implies that the form of employment relationship used by Uber Norway is in the gray area between an employee and a selfemployed with elements pointing in both directions. Jesnes et al. (2016b) looks closely at three labour suppliers - Konsus, Upwork and Welance -and point out that they all link freelancers with business users wanting a specific task to be accomplished, but some of them operate a stable, limited pool of agents and customers, while others service a wide range of actors on both sides. One of the companies, Konsus, organizes pay and contracts, and maintains enduring relationships with the freelancers, wanting them to earn a high share of their income through their company in order to promote quality, skill formation, and work incentives. Another company, Upwork, operates in a slightly different manner (than Konsus) as it links a large number of actors on both sides world-wide, and it appears that the company itself serves a purely technical matching function with no responsibilities for pay and contracts. A third company, Welance, falls somewhat in between the two previous cases as it provides freelancers with more specialized skills and therefore engages in more tailored matching including contractual issues to ensure that the freelancers fulfil the specific skill requirements of the user firm.

These examples illustrate how the new business concepts evolving within the sharing economy tend to blur the boundaries between standard employment relationship, other kinds of work contracts, and variations of self-employment and business services contracts. In many instances the nature of the relationship will have to be assessed in each particular case. Until more cases have been tried in court, it will be challenging for the authorities, companies, job-seekers, and the social partners to judge whether the platform and/or the customers have entered into a contract of employment, freelance work or business service with those being assigned to perform work via the platforms. Employment protection legislation in the Nordic countries - as well as collective agreements - tend to take as a starting point the distinction between dependent employees and self-employed, where the rights and protection of an employee are considerably stronger than those of a self-employed. As shown above, the actual variety of the relations characterizing work in the platform economy cuts across this simple dichotomy and requires more dynamic and multifaceted interpretations of labour law, where the mode of governance and the elements of subordination and dependency are likely to feature centrally (Prassl \& Risak, 2016). The legal categories and the demarcations between them in this domain are not uniform in the Nordic countries, and as the courts start disentangling the issues it would be no surprise if the politicians will have to adjust and clarify the statutory frameworks. As highlighted by Hotvedt (2016), the

protection from discrimination. As Uber works with approximately 40,000 drivers in the UK, the obligation to pay taxes on behalf of its drivers is no small matter. 
legal definitions of workers and self-employed do often also vary between labour law, tax law, and social security law, at the same time as the scope of who is protected vary between different parts of labour law. Therefore, if platform work continues to expand, the blurring of the boundaries between different categories of employment relationships is likely to increase the workload also for the ultimate arbiters and makers of law in the Nordic countries. More importantly, however, the substantial character of the employment relations that are evolving is not only likely to have significant consequences for the actual conditions of work, pay, and social security for those labouring in the sharing economy, but also to affect conditions for employees in firms competing with and/or externalizing tasks to the platform providers.

\subsubsection{Pay and working conditions: Upgrading, downgrading or polarization?}

A major selling point for the platform companies is that they will give many workers more freedom, flexibility and control over when, where, how, and how much they work. More skeptical voices, however, claim that it will lead to poorer and more uncertain working conditions especially in the lower end of the labour market. The degree of freedom and flexibility enjoyed by the worker depends indeed on how much the sharing economy workers have to work to earn a living, what type of jobs they perform, and how easy it is to obtain such assignments. As of today there is scant knowledge about this.

In the Nordic countries, the platforms mediating work have so far mainly entered low wage sectors, such as cleaning, transport, hospitality, child care, home services etc. where high immigration and competition for jobs might accentuate the risk of wage dumping. Workers within such industries are often more vulnerable than workers in high-skilled occupations. Some platforms have gone into markets for more advanced, skill-intensive services e.g. related to ICT, design, PR, text-writing, lay-out etc., and some of those are also present in the Nordic countries (f.ex. Upwork; MB Flex; Engineer.it). In practice, however, it seems so far that only a tiny part of their tasks are channeled to Nordic providers, presumably due to the vast international costs differentials and the fact that most high-skilled Nordic labour prefer and have access to more stable jobs. There are clearly certain layers of freelancing professionals among which search for work through platforms is spreading, but the bulk of jobs at hand in the sharing economy appear to be fairly low-skilled, modestly remunerated, and territorially bound. For those of the former with especially attractive skills, the platforms may open access to lucrative global customer markets, while for the latter the jobs at offer appear concentrated at the less lucrative fringe of the local market. Thus, the working conditions of the jobs available for Nordic job-seekers in the sharing economy seem thus so far to be quite polarized and with a predominance of low-skilled "mini"-jobs often associated with shifting sites and precarious working conditions. In such contexts, the likelihood that proper health and safety protection is in place is supposedly not high.

As to the quality of work in the sharing economy, early international studies have highlighted two issues of concern: the risk for dumping of wages and working conditions, and the scant opportunities for voice and autonomy in conduct of the work 
(Eurofound, 2015). Firstly, the risk of substandard pay and working conditions seems higher in international contexts, than what it is in the well-regulated Nordic countries. Eurofound has shown that the earnings of international crowd workers are very low, for instance the hourly rate on Amazon Mechanical Turk - a crowdsourcing platform - was less than USD 2 (EUR 1.9). Jesnes et al. (2016b) report that Norwegian companies pay their freelancers considerably more than Amazon Mechanical Turk. Yet, one of the firms reports that it pays between EUR 9.50 and 19 an hour, which is definitely not much for skilled work in a Norwegian context where, in comparison, the extended minimum wage e.g. for cleaners is NOK 169 (about EUR 19) and for unskilled construction workers NOK 174 (about EUR 19.50). In Denmark, Rasmussen \& Kongshøj Madsen (2016) refer to the CEO of Meploy - a platform company brokering small work "ploys", mini-jobs, in Copenhagen - who has explicitly stated that the firm aims to take into account the worries of the trade unions (Svansø, 2016). Thus, the hourly pay level of DKK 150 (EUR 21) is calculated in order to allow the workers to pay for pensions and insurance in addition to the minimum wage for unskilled workers in the collective agreements. A fee of 5 percent is charged by Meploy. To avoid tax evasion, the firm has also set a limit, so people who do not have a VAT number are blocked from seeking new jobs, when they have earned more than DKK 50,000 (EUR 6,700) in a year. Another requirement is that it must be possible to complete the task in between 1 and 7 hours. AHandyHand.dk, which is similar to MePloy, has existed since 2009 and covers the entire country. The jobs available on AHandyHand range from "handyman-like" tasks, babysitting and cleaning to computer assistance. According to the website around 6,000 persons offer their help and as opposed to MePloy no fixed hourly pay exists, but the website has examples of what is appropriate pay for different tasks ranging from DKK 60-100 (EUR 8-13) for individuals below the age of 18 and DKK 100-300 (EUR 13-40) for individuals over the age of 18 . There is no upper limit as to how many hours the individuals can spend to complete the tasks. Comparing the minimum wage in some collective agreements with the hourly pay from the labour-exchange platforms, the latter do not seem to be totally out of line in Denmark either. However, it should be added that the average wage for unskilled adult workers is significantly higher than the collective minimum wage - around DKK 200 per hour in 2014 (around EUR 27) (Rasmussen \& Kongshøj Madsen, 2016).

According to the Swedish background report (Rolandsson et al., 2016), the survey carried out in Sweden by the University of Hertfordshire suggests that people are increasingly associating themselves as providers in the gig/sharing economy (Huws \& Joyce, 2016a). Even if the income that Swedes earn through this type of labour can be described as modest, many of those who partake more frequently see themselves as dependable on it. According to the study, this challenges a common understanding that this kind of work is only done for altruistic reasons or is mainly seen as an occasional income. Furthermore, the report states that many of these individuals are stepping out of their normal occupational role, offering themselves to do a variety of work, both from home (online) as well as offline, e.g. gardening work, cleaning etc. (ibid). Another concern is that although platforms have advanced payment systems, the rating systems in place in many companies, where the client and the freelancer rate each 
other after the job is performed, may lead to insecurity about pay issues (Eurofound, 2015: 8). In some instances, pay is not received before the customer or the platform is content with the quality - an issue on which the workers usually have little or no voice - opening for extra unpaid hours and uncertainty about what the actual hourly pay for a task will ultimately be. In such instances, the risk is entirely shouldered by the worker. As the most attractive jobs might be assigned to those with best scores in the rating system, the competition on prize and quality between freelancers - having no information about what the others are offering - can be supposed to be fierce. A sideeffect might thus be a stressful and straining psychosocial work environment (Jesnes et al., 2016a; Berg, 2016), adding to the basic uncertainty regarding the chance of landing enough jobs to earn a living for those who rely on platform work.

Secondly, Eurofound (2015) addresses the opportunities for voice among the sharing economy workers. As the weaker and most vulnerable part in the triangular relationship, the workers will normally have scant opportunities for voice regarding the content of the assignments, the quality required, and the terms offered for delivering it. In contrast to ordinary jobs where there are institutionalized procedures for resolution of grievances and disputes, the self-employed have not access to such mechanisms. To the extent that the protections and rights associated with ordinary employment apply, the dispersed and fragmented situation of the individual workers is likely to make it difficult to raise issues with the counterpart, be it the digital platform or the customer, or to represent their interests and demands in collective ways (Stefano, 2016; Berg, 2016).

In the Swedish digitalization investigation, the sharing economy is discussed in view of broader social processes of individualization (Fellman, 2015: 91). Referring to the investigation's strong emphasis on entrepreneurs, the Swedish country report (Rolandsson et al., 2016) points out how the focus on the entrepreneurial role of the individual, on the one hand, is implicitly associated with neo-liberal ideas about the free market, and on the other hand is embedded in a discourse where the individuals are increasingly made responsible for construction of their own lives and life-courses (Beck \& Beck-Gernsheim, 2002). In this perspective, the expectedly rising group of social entrepreneurs is both taking advantage of the sharing economy as a self-made, resource-rich autonomous actor - making the most of the opportunities offered by the possibility to compete by offering his/her skills on a global scale - and being struck by strainful demands for being constantly able not only to sell him/herself but also to improve the ratings required to maintain her/his attractivity in the digitalized market. In spite of the standardized terms of the matching processes, the ability of the individual to develop social skills, thinking in terms of networking, and to promote themselves as a personal brand through their websites and interaction with the clients are becoming ever more crucial (Insightlab, 2015; Fellman, 2015). Clients and customers are increasingly interacting in ways where social media are used to inform others about their dis/satisfaction with using various rating systems, including systems that rate performance on the individual level. Yet, this also entail opportunities to muster countervailing power, as through the collaboration between Unionen and the German IG Metall which has enabled platform-workers to share information and warn each 
other against dubious customers e.g. not paying what was agreed, demanding undue extra work, quality or alike (Arbetet, 25.10.2016, in Rolandsson et al., 2016).

Compared with the visions of liberty and freedom to choose when, where, how, and how much to work, the direct exposure to the vicissitudes of the market for parceled job- tasks ("gigs", ploys etc.) and the platforms' anonymous, unilateral mechanisms for control and supervision, imply that working in the sharing economy can often prove less seductive and attractive than at first sight (see f.ex Berg, 2016; Stefano, 2016; Jesnes et al., 2016a). While the innovative forms of collaboration and matching of complementary skills and needs clearly can unleash productive synergy effects and open up interesting opportunities for actors with attractive skills and market power, the routinization, standardization, and strict control of the parcelled, digitalized microtasks where skill requirements are modest and the supply of (global) bidders in principle boundless entail obvious potential for degradation and polarization of work.

When the basic institutions of the regular employment relationship once evolved such as legislative protection of workers' health, safety, and the right to organize and negotiate freely with their counterparts - the raison d'etre was to shield the workers from the volatility of the market and the recognition that labour was not simply a commodity like other input factors in production but also a human activity inherently bound to the persons conducting it (ILO, 1919). ${ }^{29}$ Hence, a key feature in the historical evolution of industrial relations was the enactment of procedures and rules regulating the mutual relations and boundaries between management's right to lead and workers' right to voice, negotiation, and exertion of independent collective pressure to influence and improve the conditions of work. Compared to the early era of industrialization and exodus of labour from agriculture when the individual labourers bid for work in fierce competition with each other and the employer could divide and rule, this was indeed a huge leap towards a civilization of employment relations which enabled a liberation of the productive potential of human labour. As labour was a major input factor in production, the security provided by the regular employment relationship improved employers opportunities to benefit from labour's innate skills, energy, and ability to improve the organization, sharing of knowledge, skills, and execution of the work processes.

Enabling a break-up of the traditional notion of the firm and the employment relationship, the digital technology platforms tend to replace the mutual ties between employer and employee by standardized, scripted relations between independent demanders and suppliers of labour services where the latter have scant opportunity to influence or negotiate the terms of exchange. Hence, those providing labour in such triangular transactions risk in many respects being brought into a situation resembling that of the pre-industrial era (Siltala, 2016, in Saloniemi, 2016) infamously described in Marx's analyses of the French parcel peasants in the 19th century..$^{30}$ The effects of this kind of mechanical division of labour and the relations of authority between the platforms

\footnotetext{
29 The thesis that "Labour is not a Commodity," was central when the International Labour Organizations was established in 1919 as part of the Versailles treaty, and before that in the first sentence of Section 6 in the US Clayton Antitrust Act 1914 (see Evju, 2012b: 8).

$3^{\circ}$ In his writings about "The Eighteenth Brumaire of Louis Bonaparte" published in 1851, Marx highlights the atomized and disempowered position of the parcel peasants under feudalism.
} 
and the providers of work are very different from the mutual complementarity and interdependence that according to the French sociologist, Durkheim, gave ground for the evolution of organic solidarity in modern societies and working lives (Durkheim, 1893).

The changes in the labour market opened up for by the sharing economy thus entail potential for a reversal of the institutionalization of work and its de-commodification enshrined in the 1919 ILO's statutes and the associated social security rights ensured by the welfare state where duties and rights are intimately coupled with wage labour (see e.g. Siltala, 2016, cited in Saloniemi, 2016). However, the possibilities for deinstitutionalization and re-commodification of labour inherent in the platform technology do not necessarily imply that such a development will occur. That depends on how the employment relations develop when the platform companies mature and when governments, social partners, and those working in the crowd economy figure out how to respond to these challenges. Internationally there are examples that "gigworkers" have begun self-organizing in order to protect and improve their situation (see for instance The Independent Drivers Guild; Uberpeople.net).

Summing up, the little there is of preliminary studies of platform work do indicate that there are reasons for concern with regard to insecure earnings, work environment, employment conditions, health and safety as well as with regard to opportunities for dispute resolution and labour voice. The flip-side of the liberty and autonomy promised in the sharing economy can for crowd-workers who operate at the mercy of the markets for assignments therefore be an extent of dependency, power asymmetry, atomization, and subordination vis-à-vis their interlocutors that the institutions of the ordinary employment relationship were originally invented to eradicate. Hence, the employment and working conditions of the producers in the sharing economy deserve further scrutiny and will both from a political and research perspective be important to follow in the years to come. Besides analyzing what kind of jobs that are moved out on the platforms, it will be interesting to trace how the pay, earnings, and working conditions of the sharing economy employees evolve compared with those of other employees doing similar work.

\subsubsection{Platform workers and social security}

The present systems of public social security and welfare services in the Nordic countries are closely tailored to the wage earner relationship (Saloniemi, 2016). Entitlements to income security and benefits are commonly earned through the income and number of years in salaried work, and the funding of the welfare system relies on contributions from employers and workers. ${ }^{31}$ The predominant reliance of the sharing economy platforms on the labour providers operating as independent freelancers or business contractors, has raised concern among politicians, social partners and the gig-workers themselves that they will fall between the stools in the

\footnotetext{
${ }^{31}$ Denmark is a Nordic outlier in this respect, by not requiring employers to pay social security contributions for their employees (pay-roll taxes) to the state, leaving a larger share of the funding of the welfare state to the employees and other forms of personal and indirect taxation.
} 
Nordic welfare systems. Generally distinguishing between employees, freelancers, and providers of business services, the former are in the Nordic systems entitled to a broad range of benefits (the "social wage") and the latter have to cater for most of their income maintenance insurance themselves, while the freelancers fall in an intermediate position with a limited set of rights. Far from all young people enticed to work as self-employed are aware of these discrepancies and the consequences of not earning rights to the (full) social wage. According to the Swedish background report (Rolandsson et al., 2016), most Swedish studies and policy documents point out that the current social security system is a product of the tradition for permanent employment, and have to be adjusted to changes toward an economy characterized by more flexible and fluid modes of employment (Braunerhjelm et al., 2014).

In view of the population ageing's impact on welfare state finances and services, there are reasons to expect that the politicians' prime focus will be on how they can cater to the majority of existing constituencies that already have earned or been assured their entitlements. Entering an era with more pressure on the public coffers, it is thus far from obvious that the Nordic "wage earner" welfare states are able or willing to take on full responsibility for new and growing groups, unless they and the platforms they work for contribute to the public finances on an equal footing. Accordingly it seems that a central precondition for the sharing economy' opportunity to grow and gain legitimacy in the Nordic world of work is that it - in cooperation with other societal actors - finds ways to ensure its value-creating producers proper social insurance including decent income security, sickness pay, vacation, pensions etc. If the state is not able or willing to resume this responsibility, it will at any rate have to provide a regulative framework that obliges the involved actors to secure the producers such rights. If the latter option is chosen, it may open new space for provision of such services either by private business actors or by the social partners who have a long tradition for negotiating and providing collective funds for this kind of purposes, typically illustrated by the longstanding unemployment benefit funds ("A-kassene") and occupational pension funds.

In several Nordic countries there are examples that both avenues are being tried. For example, in Sweden many self-employed (egenanställd) are paying specific companies for taking care of social security fees without being employed by them. In Norway and Sweden, Cool Company is developing similar functions, taking on some of the technical employer responsibilities (www.coolcompany.com). In contrast to such outsourcing of the public social security responsibilities of the employer, one can also envisage that the actors in the sharing economy may choose to opt out of the welfare state and rely entirely on private insurances. The other avenue is for instance being tried out by the Danish retail union (HK), providing pension-fund services for self-employed (see section 3.3.2). With the dense networks of private, collective, and public actors involved in the provision of social security in the Nordic countries, and the competition for members and contributors likely to evolve in this field, the sharing economy may open space for social entrepreneurs that can propel new forms of institutional innovation and private-public partnerships in the Nordic welfare regimes. Nevertheless, given the actuarial logic governing insurance, the provision of such services can readily 
become biased towards the more resourceful groups of actors who are able to pay good fees, while those being left to seek out a living with occasional micro-jobs in local markets run a risk of getting a poorer deal. In such a perspective, it is reason to expect that the Nordic systems of insurance and entitlements in the labour domain will enter a period of revision and adjustment (Fellman, 2015; Unionen/Söderqvist, 2016) where the countries may benefit from mutual learning and exchange of policy ideas, experience, and research based knowledge.

\subsubsection{Implications for the broader labour market-jobs, matching, modes of competition}

Besides the direct impact of the platform economy on the employment conditions of the workers involved, proliferation of platform work might influence the functioning of the labour market in the industries and occupations with which they interact. With the presently limited size of the sharing economy, no empirical studies of such effects are undertaken in the Nordic countries. Yet, if the platform economy should "take off" there are certainly questions arising as to how the new commercial forms of matching in the job market - enhancing outsourcing of tasks - will influence employers' willingness to hire equivalent labour on regular contracts in-house, their organization of work, and the terms offered. The opportunity to concentrate more on core activity and outsource ancillary services may reinforce recent trends towards externalization of work e.g. to subcontractors and temporary work agencies (TWAs). This may in turn strengthen pressures for cutting of internal labour costs and splitting of jobs into parcels of standardized tasks, or mini-jobs, suited for universal subcontracting. A likely consequence in such a scenario is that the labour market becomes more segmented while those working in the user, or client, companies may become subject to stricter hierarchical control, supervision, and benchmarking of tasks in order to assess whether it can be justified to continue doing such tasks in-house. To the extent that the prices of the external sharing economy providers become a benchmark for internal work organization and staffing policies, the scope for teamwork, learning by doing, and investment in long term skill formation may also diminish. In effect, fiercer product market competition can spur more direct forms of job competition between workers, transcending the division between internal and external as well as between national and international labour markets.

In the debate about globalization and decent work, much attention has been paid to the corporate responsibility of multinational companies organizing production through international chains of subcontracting. E.g. in the textile and garment industry, much energy has been spent on securing and supervising that the terms and conditions of the workers are in accordance with ILO labour standards and international company codes of conduct (OECD Guidelines for multinational enterprises, ILO's decent work agenda, UN Guiding Principles on Business and Human Rights). By contrast, many companies outsourcing tasks to freelancers abroad through platform intermediaries have reportedly little or no knowledge of the actual employment conditions of the producers. Through the digital contact with the producers, the opportunities to obtain 
such information should in principle be readily available if the platforms so allow and are willing to cooperate.

Nationally, the evolution of triangular employment relationships has led to statutory and negotiated regulations of how the pay and conditions of third-party workers are to be determined. The most recent example is the EU temporary agency work directive (2008/104/EC) which stipulated that agency workers are entitled to equal treatment, that is, the same basic working and employment conditions that would apply if they had been recruited directly by the user company. Earlier on, similar rules have been developed nationally through collective bargaining and sometimes by statute. As a new but comparable instance of triangular labour relations, one might imagine that resembling rules eventually are developed to regulate the rights and duties of the actors involved in labour intermediation through platforms. The Swedish white-collar federation, Unionen, has for instance suggested that organization, authorization, and regulation by the social partners along the lines practised in the Swedish temp agency sector could also be applied in the platform economy (Unionen/Söderqvist, 2016).

Beyond the questions pertaining to the effects on job competition, matching of skills, and work organization in the affected industries, a looming, overarching question is to what extent the new platform companies actually will contribute to creation of more jobs, employment, and production - or whether they will mainly contribute to a reshuffling of jobs, tasks and income between the involved parties. Many observers and promotors of the sharing economy seem convinced that the former is the case, and that the potential for enhanced growth and job creation is huge. Those being of a more skeptical nature - or being less close to the industry- tend to adopt a more sanguine view. First, on a global scale, there are good reasons to assume that the reduced time and costs of transactions and the eased matching of tasks and skills in footloose digitalized services entail significant potential for net growth in production and jobs. Nordic user companies may hence benefit from increased demand and reduced input costs, whereas some of their Nordic sub-delivery firms may experience reduced demand and profit margins. How much of the global growth in the sharing economy that will occur in the Nordic countries with their high labour costs, however, is a different question. A further question is how the expansion of the asset-based part of the sharing economy will influence the growth in investment and consumer demand which hitherto has been the engine for economic and employment growth internationally and nationally (Staab, forthcoming 2017). Whether the sharing economy will lead to net job gains or losses in the Nordic countries is thus too early to assess. As the focus of this study has been on the impact of the directly work related parts of the platform economy, it has been beyond the scope and capacity of this pilotproject to dive into such fundamental, long-term questions.

Second, within the advanced northern European countries, there are certainly also productivity gains to be reaped by a better matching of advanced skills and deliveries as indicated by the longstanding growth in the consultancy sector - but how much net job gains or losses that can be expected from a more efficient, digitalized allocation of human resources is hard to predict. The more advanced services and complex skills that 
are involved, however, the more emphasis is apparently laid on durable customerprovider relations - enabling mutual problem-solving, learning, dialogue, and trustbuilding - suggesting that more institutionalized forms of cooperation are often preferred. As to skilled platform services, the most promising domestic growth area in the Nordic countries may therefore seem to be in ancillary services that lend themselves to standardization, rationalization, and outsourcing. Such subcontracting has been going on for a long while in non-digitalized forms, and apart from its costsaving potentials it is an open question to what extent a further twist in this direction will mainly lead to more jobs or higher productivity.

Third, the remaining area where one can expect a substantial potential for jobcreation in the sharing economy is the market for simple, territorially bound labour intensive services such as cleaning, transport, maintenance, private care, gardening, dog-walking, and so on, in the local community. In the business-market it is not evident that hiring of e.g. cleaning or transport services via a platform would generate more jobs than hiring a company on the phone. The market for labour intensive services to private consumers, however, has expanded steadily in most countries including the Nordic in recent years. With rising affluence in the middle classes many groups become more inclined to buy services they formerly used to do themselves. The easy availability and frictionless transactions offered by the platforms are likely to give the demand for such services a boost. Still, at the end of the day the lion share of the price for such work is determined by the costs of labour. Assuming that the taxation issue is resolved, and that wage setting in this domain is largely unregulated, the size of the market for such services depends on where the consumers' demand curve intersects with the supply curve for labour willing to undertake such occasional jobs. Traditionally in the Nordic countries, the reservation wage has been coupled with the levels of unemployment benefits and the lowest pay clauses in relevant collective agreements, implying that the number of consumers willing to buy this kind of services at a price corresponding to such wages has been limited. With the rise in migration and many young people dropping out of school and not finding a regular job, the supply of people willing to work for lower pay has probably increased. Further, government policies aimed to boost consumer demand for domestic services by allowing tax exemptions, typically the Swedish ROT \& RUT deductions ${ }^{32}$ together with stricter activation requirements in social policies, have tended to spur both consumer demand and labour supply, suggesting that the volume of the market is growing. Given that the effects of these reforms have been underway for a while - except in Norway where such schemes are not introduced - the question is how much the digital intermediation of such jobs will add to the present level of demand and supply. Easy availability and flexibility is definitely a factor that may alter the behavior of some of the actors, but the market for low-paid work will probably not expand substantially unless the wages are brought down by further shifts in labour supply, i.e. that the pool of people willing to work for lower pay increases. Although the availability of jobs with ordinary wages and

${ }^{22}$ These are tax exemption schemes applying to purchasing of various forms of domestic services, see https://www.skatteverket.se/privat/fastigheterochbostad/rotochrutarbete.4.2e56d4ba1202f95012080002966.html 
conditions is still pretty high and the level of unemployed without access to benefits is fairly limited, except perhaps in Finland, there are probably untapped sources of labour that might seek occasional, extra work if it was readily available. Besides the influx of labour migrants and the growing immigrant populations, all the Nordic countries have sizeable shares of working age people employed in temporary, part-time and shorttime jobs, often with limited access to extra work and income. In the years ahead the number of healthy and vital retired people will also increase rapidly. With easier access to the digital job market, some of those can probably also be enticed to do some casual work and add onto the pension.

Altogether, it is at this stage very difficult to assess the potential for job growth provided by the sharing economy. It is ceteris paribus pretty safe to presume that the size of the territorially bound lower end market for digitalized service work will depend heavily on how the ordinary labour market will develop. With prospects for sluggish international growth and a digital fourth industrial revolution where sizeable groups of workers with standard jobs can be made redundant - in Nordic as well as other European countries - one cannot preclude that the supply of native as well as migrant labour in this part of the job market can increase markedly. In a labour market policy perspective it will thus be important to monitor the development in supply and demand for platform work in the years to come.

Whatever scenario is most likely, in order to maximize the benefits and minimize the costs of the sharing economy in terms of job creation, there is certainly a need for renewed patterns of governance in this part of the digitalized economy. Especially in the well-organized Nordic working lives where most people are used to, and have access to, more predictable jobs and earnings, that appears as an important precondition for making platform work an attractive, competitive, and legitimate option. That we turn to next, exploring the approaches to sharing economy work among Nordic governments and social partners.

\subsection{Social partner and governmental responses on work life issues}

Given the early stage of the sharing economy, it would come as no surprise that the Nordic governments and social partners have so far come up with very few policy initiatives aimed to facilitate and shape its further evolution. All the Nordic governments have indeed welcomed the sharing economy's potential for growth, innovation and job creation. Emphasizing the importance of avoiding premature regulations that might hamper its evolution, they have also acknowledged that new challenges may arise. Considering the uncertain direction and significance of the sharing economy's development, they have evidently preferred to await further information about how things evolve before figuring out how to proceed and concretize their strategies. Apart from the field of taxation, 33 where most governments have

33 Here most Nordic tax authorities have clarified thresholds and criteria for when individuals engaging in the sharing economy have to pay tax on their income, e.g. for renting out rooms through AirBnb, and have worked with the platform to 
adjusted thresholds for tax on income from renting assets (cars and housing), the Nordic governments have so far done little with the rules of competition, employment relations, and social security rights. In response to the quandaries with Uber, however, Finland has decided to liberalize competition in the taxi sector from 2018, except for the fact that drivers will be required to master Finnish language (Saloniemi, 2016).

In 2017, the political agendas and debates are likely to become clearer, as the government appointed investigations in Sweden and Norway as well as the sharing economy strategy of the Danish government will all have been presented. The contours of the EU approach may also have become clearer by then. In table 1 (next page), we present an overview of some of the issues that are likely to occupy the institutional actors in the years ahead. The social partners have naturally awaited the material from the governments, but they have to varying extent also engaged in influencing the debate by pointing out their concerns and developing various position papers (LO, 2016a,b; Unionen/Söderqvist, 2016; Ilsøe 2016, forthcoming 2017). On this background, we will in this section mainly concentrate on the initial responses of the social partners, which might have a central role to play in shaping the evolution of platform work in the Nordic countries.

Table 1: Renewal and preservation of Nordic regulatory regimes and institutions: Some tentative examples of policy ideas and tools

\begin{tabular}{|c|c|c|}
\hline \multicolumn{3}{|c|}{ Policy ideas and tools with impact on the labour market - tentative examples } \\
\hline Taxation \& Welfare State & Level Playing Field & Employment Relations \\
\hline $\begin{array}{l}\text { Renew international tax regimes } \\
\text { (MNCs), ex. Uber case }\end{array}$ & Secure equal basic tax burdens & $\begin{array}{l}\text { Public requirements to contract terms \& } \\
\text { conditions }\end{array}$ \\
\hline $\begin{array}{l}\text { Alter tax thresholds e.g. for asset } \\
\text { renting }\end{array}$ & $\begin{array}{l}\text { Adjust access barriers: Technology } \\
\text { neutral regulations? }\end{array}$ & $\begin{array}{l}\text { Extend core minimum terms in law or } \\
\text { CAs to "selfemployed"? Statutory } \\
\text { minimum pay? }\end{array}$ \\
\hline $\begin{array}{l}\text { Widen company duty to pay social } \\
\text { charges? }\end{array}$ & $\begin{array}{l}\text { Reform rules for licensing and } \\
\text { authorization? }\end{array}$ & $\begin{array}{l}\text { Establish bodies for voice and } \\
\text { compulsory dispute resolution? }\end{array}$ \\
\hline $\begin{array}{l}\text { Indirect taxes: Assess VAT base? } \\
\text { New forms of transaction levies? }\end{array}$ & $\begin{array}{l}\text { Coordination within employer } \\
\text { organizations: Platforms and user } \\
\text { firms vs competitors? }\end{array}$ & $\begin{array}{l}\text { Organizing platforms? Codes of conduct } \\
\text { defined by employer organizations? }\end{array}$ \\
\hline $\begin{array}{l}\text { Compulsory social \& pension } \\
\text { insurances? }\end{array}$ & Reassess the base for payroll taxes? & $\begin{array}{l}\text { Clarify legal concepts of employee, } \\
\text { freelancers etc. }\end{array}$ \\
\hline Collective funds, f.ex. HK-Denmark & $\begin{array}{l}\text { Framework agreements levelling } \\
\text { labour costs? }\end{array}$ & $\begin{array}{l}\text { Organizing freelancers? Negotiate CAs } \\
\text { with binding rules like in Swedish TWA? }\end{array}$ \\
\hline
\end{tabular}

Source: Dølvik \& Jesnes, 2016.

obtain instant access to payment information (see http://dx.doi.org/10.6027/TN2017-508). More complicated is evidently to get the international platform companies established in foreign countries to pay taxes on the incomes stemming from activities in Nordic and other countries. E.g. in Uber, all payments are channelled through the branch in the Netherlands. Danish authorities have so far been successful in getting information from Dutch authorities about the income of Uberdrivers in Denmark (Politiken, 30.09.2016). 


\subsubsection{The employer and business associations: Laidback wait and see approach?}

The peak associations on the employer and business side have generally adopted a "light touch" approach and emphasized the need not to strangulate the nascent industry by excessive or premature regulations. Most clearly, a representative of the Confederation of Danish Employers (DA) recently stated that existing regulation is sufficient to cope with the challenges from the sharing economy (Rasmussen \& Kongshøj Madsen 2016). Most employer associations have been silent as regards issues pertaining to employment status, pay determination, and labour and social law, presumably preferring not to show their cards in the forthcoming encounters with the union counterparts. When it comes to their member companies' interest in maintaining a level playing field vis-à-vis the new actors, several sectoral employer and business federations - typically in taxi transport and hospitality - have engaged in the field of taxation and regulation of competition and access to particular trades. Here the peak associations have trodden carefully, as these are typically themes where different member federations can have conflicting interests - as is likely to be the case also when it comes to labour costs and workers' rights.

In an independent report commissioned by the British government - "Unlocking the Sharing Economy" - the establishment of a central branch association for platforms is commended. 34 To our knowledge, comprehensive organizing efforts of this kind remain to be seen in the Nordic countries, but several associations organizing technology companies, illustrated by Abelia (NHO-affiliated) in Norway, have been eager to recruit the platform companies and to promote their interests towards the government. Federations of employers that may end up competing with the platforms - typically in cleaning, hospitality, and transport - have sometimes been less enthused about such initiatives, as the boundaries between employer federations are normally based on industrial principles. Federations organizing companies that are outsourcing tasks to providers via platforms may on their part have interests diverging from the competitor and delivery companies e.g. when it comes to issues influencing labour costs and prices for the users. A familiar example is the strife over regulation of terms and conditions in the temp agency sector where such tensions became highly salient in the negotiations on the European level and are well-known in the Nordic countries as well. ${ }^{35}$ In short, the perceptions of self-interest and lines of division on the employer side are likely to depend on how the sharing economy will influence the competitive position of member firms in different industries. A challenge for the peak associations will hence

\footnotetext{
34 Independent report, Unlocking the sharing economy: independent review (Department for Business, Innovation \& Skills, 26 November 2014). The branch association for sharing economy companies is in the report seen as a means to promote " best practice", pooling of resources, development of soft regulation through codes of conduct, guaranteeing fair conditions and remuneration in accordance with "the living wage" defined by government, and provide consumer certification to platforms complying with the criteria. Eventually such an association has been established - Sharing Economy UK (SEUK) - and the development of branch standards is assigned to researchers at Oxford Said Business School to avoid infringement of competition law (Unionen/Söderqvist, 2016).

35 For example, in Norway there was significant tension between the NHO federation organizing temporary work agencies and their sister federations organizing companies using temp agencies when it came to how the EU directive on temporary agency work should be implemented.
} 
be how to balance these conflicting interests with the general interest in promoting growth in companies that over time might boost the membership.

\subsubsection{The trade unions: Protecting core constituencies or embracing the self-employed?}

From the outset, all the main Nordic trade unions - generally in favour of technological renewal - have adopted a positive view of the sharing economy's potential for innovation and growth. But in their various position papers, they have underscored their concerns regarding pay, employment conditions, labour relations, and social security for the platform workforce (see e.g. LO, 2016a, b; Unionen/Söderqvist, 2016). The basic issue for the trade unions is how the sharing economy platforms will influence the terms of competition in the labour market; that is, first, the determination of pay, working conditions, and social rights for the platform workers, and, second, how these may affect conditions for workers in companies competing with or using platform labour. As associations aiming to represent all working people, key aims are to secure the platform workers decent, equitable employment and social conditions, and to ascertain that all firms and workers pay their fair share of the taxes funding the welfare state. Emphasized by trade unions in all Nordic countries is thus that the laws ought to be clear on when you are an employee and when you are self-employed or a business contractor.

With respect to state development of taxation, competition, and basic social security rules that balance the terms of competition between platform companies and other enterprises, the trade union confederations can be supposed to share considerable common ground with their employer counterparts. Both sides probably see an interest in prodding governments to adjust social security legislation so that selfemployed are ensured a proper safety-net. The configuration of interests is likely to become more complicated when it comes to pay, working conditions, and rights for platform workers. While unions' central interest is to secure that the platform workers get pay and employment rights that are comparable with other workers in the same industry, the employer side is likely to become more divided between platform companies, their users, and their competitors. Such differences are usually less pronounced among the trade unions, but a dilemma for them is that it must not be too attractive for workers to become free-lancers and not too legitimate for employers to hire platform labour instead of ordinary employees. All this may bode for interesting dynamics of conflict and coalition-building across and within the counterpart confederations. Union attitudes and views can be expected to vary more when it comes to development of concrete policies and strategies that may also require pooling of scarce resources. While some unions are familiar with organizing freelancers or bargaining on behalf of externally hired labour, others have more traditional notions of such work arrangements, and the resources available for joint initiatives vary profoundly. Further, union views on organizing and promoting the interests of freelancers are likely to be influenced by whether they organize vertically, and are used to serve different occupational groups, or organize horizontally and usually only cater to an occupationally homogenous membership. 
Several Nordic trade unions have already been exploring how they can recruit freelancers, and discussed where they ought to be organized - in many instances not an obvious issue. In Denmark, HK, organizing salaried workers, has recruited new personnel and trained their employees in order to offer better assistance to members, if they ask for advice in relation to take work through a Danish or foreign platform (Rasmussen \& Kongshøj Madsen, 2016). Along similar lines the Danish Confederation of Professional Associations (AC) has asserted that the unions clearly have a role to play in ensuring the rights of the new independent workers. Together, the two unions have announced that they will establish a task force of experts, which will come up with concrete solutions to some of the many challenges that follow in the wake of platform economy. The task force will consist of leading representatives of IT companies, platform companies, trade unions, employers and researchers (ibid). In Finland, the service sector union, PAM, has started offering new services to non-standard workers, while the confederation for professionals, AKAVA, has begun organizing self-employed (Saloniemi, 2016). So far, Swedish LO has not published any formal reports on the subject. Due to the fact that they will be part of the state initiated public inquiry about the impact on work environment legislation, they have however formed a group that are about to look closer at the opportunities and consequences of the sharing economy (Rolandsson et al., 2016)..$^{36}$ Unionen, a white-collar union which is the largest union in Sweden (affiliated to TCO), has come a bit further in developing its approach towards the sharing economy. Organizing seminar series and producing a large report, it has developed a set of visions and quite elaborate ideas about how the social partners can cooperate in self-regulation of the platform companies' activities along the lines pursued in the temporary agency sector (Unionen/Söderqvist, 2016). LO Norway has also established a group "LO selvstendige", with members from different trade unions, that will explore whether and how LO should approach the freelancers. Some of its member unions have launched parallel initiatives, for example the union IndustriEnergi organizing amongst other in the petroleum sector where the use of independent contractors has grown recently. Given that there is not yet any available counterpart with which platform workers can negotiate, a core question being discussed among the trade unions is what they can offer the sharing economy workers. Do they need more tailor-made offers for these workers - e.g. in the area of social insurance, legal and tax advise etc. - similar to that of Cool Company and others catering to the freelancers? And what can be learned from the varied Nordic unions' experiences with setting up digital unions or services for atypical workers?

A possible alternative trajectory is that the platform workers will prefer developing their own less formal ways of self-organization and collective action (example: Uberpeople.net, Independent Drivers Guild). Whether such embryonic forms of organizing can evolve into new patterns of interest representation and

\footnotetext{
${ }^{36}$ In contact with the author of the Swedish background report, the coordinator of the LO group referred to the status of self-employed, the responsibilities of the company running the platform, and its relation to anyone conducting work on their platform, as key topics that will be discussed (Rolandsson et al., 2016).
} 
eventually will enter into cooperation with trade unions or other civil society movements remains to be seen.

If the trade unions aim to regulate platform work by negotiating some sort of framework collective agreements, the immediate question is, as mentioned, who might be positioned, willing, and mandated to step up as employer counterpart. Historically, collective agreements emerged from the company level, but it is likely to be a long march to organize and sign agreements with the mushrooming platforms one by one. More recently, the well-organized employers in the Swedish temp agency industry were enticed to enter agreements through pressure from above, entering central accords with the respective trade union confederations for blue- and white-collar workers. This example highlights the pivotal role of employer associations in promoting organized relations in new sectors with fluid and fragmented workforces. Inspired by ideas from the British branch federation, SEUK, Unionen in Sweden has in the same vein suggested that the social partners organize platform companies and set up a joint social partner platform defining agreed labour standards and providing authorization for platforms fulfilling the requirements (Unionen/Söderqvist, 2016). In Denmark, a different model is applied by which the organizations in the user industries have agreed to apply the conditions in their agreements on equal terms for agency workers. In Norway, such a solution requires that also the temp agency firm in question has signed the CA of the user industry. In Finland, Iceland, and Norway, extension of collective agreements in the user industries will also cover employees in platform companies - and one could perhaps imagine legislative innovations that widen the effects of extension to include freelancers. In the case of selfemployed, typically among musicians and artists, there are also unions that have negotiated framework agreements with the organizations of the customer companies defining standard provisions and guidelines for various aspects of their contracts and working conditions. Regarding social provisions such as occupational pensions, training, child care, and alike, there is as earlier mentioned a range of examples that Nordic unions have negotiated arrangements with the employer counterparts. Others have unilaterally organized collective funds for their members or used their joint market power to negotiate favorable deals for their members with private insurance companies. One can even envisage trade unions jointly establishing their own platform companies, providing services and assignments for their freelance platform members. Hence, many options are at hand if the will and interest is there.

\subsubsection{It takes two for tango, but also a good bandleader?}

Clearly, if both sides of industry see a common interest in bringing the new platform companies and their dispersed workforces into the fold of the organized Nordic working life, there are paths to follow that may serve the purpose. The critical question is, however, whether the main actors perceive the sharing economy as important and influential enough to muster power and commitment to spend scarce organizational resources on a venture with uncertain gains and costs.

Experience shows that organizing small-and medium enterprises and atypical workers in the service sector is an up-hill task. A crucial precondition for developing 
proper labour relations is that the employer associations manage to organize the relevant companies, in this case the platforms. Although a couple of the Norwegian platform companies have become members of $\mathrm{NHO}$ Abelia, the philosophy among many leading platforms indicates that they can be hard to convince about the gains of going down that alley. Also the user firms might be reluctant to support collective regulation of the relations with their platform subcontractors, which would probably increase the user costs.

Very much will therefore depend on how the states approach the sharing economy, which is basically a political issue. It is hard to envisage that the social partners voluntarily are able to organize and regulate the platform labour market, unless the states provide support, credible regulative threats - as was important in the selfregulation of the Swedish temp agency sector ${ }^{37}$ - and draw up clear road maps for where they want the sharing economy to develop. Given the international character of the sharing economy, how the EU approaches the issue will certainly also play a part.

Still, labour law and social protection is in EU a national prerogative, meaning that it will ultimately be up to national politicians to make the strategic choices shaping the legal and economic frameworks for the platform labour market's development. Although there is broad support for maintenance of the Nordic labour regime, there are indeed influential parties that view more flexibility and tolerance for evolution of a larger low cost market for labour as a necessary precondition for reducing unemployment and including more of the immigrant and youth population in paid work. This side of the political spectrum may see an unregulated platform market as a suitable tool for moving in that direction, without having to engage in electorally costly struggles over reform of existing labour market regulation. Also given the marginal size of the sharing economy, adoption of a relaxed laissez-faire approach may thus appear as an easy way forward. By contrast, for those parts of the political spectrum that regard increased low-wage competition as contradictory to the legacy of high-quality, highproductivity production that has guided labour market regulation in the Nordic economies and as an engine for erosion of its institutional foundations, it may appear as a key priority to tighten the cracks in the dam by subjecting the labour intermediating platforms to stricter regulation.

Between these two stylized, protagonist strategies, the Nordic politics of coalescing and compromise might give way to a variety of policy measures and mixes. This may also lead to institutional and regulative innovation where the different Nordic actors may benefit from mutual learning and exchange. As the maturing of the sharing economy will not happen overnight, the political and organizational processes shaping its regulative and economic frameworks may well turn out to become a protracted stepwise trial and error process where nationally diverse sequences of regulation and reregulation appear more likely than a common quick fix.

\footnotetext{
37 Especially the Dutch industrial relations scholar Jelle Visser has pointed out how such political pressure on the collective market actors have often been decisive in prodding the organized actors to take responsibility for regulating new issues or areas - hence acting under "the shadow of law" or "the shadow of hierarchy" (Visser \& Hemerijck, 1997).
} 



\section{Concluding remarks - how to bridge the knowledge gap?}

In this pilot project report, we have emphasized that the platform economy in the Nordic countries is still in its infant stage. As it matures and grows, it is likely to alter interest constellations, terms of competition, and power relations among the affected working life actors. When labour standards, pay, and indirect labour costs are becoming more central parameters of competition in product markets as well as labour markets, the lines of interest coalescing and conflict will often cut across traditional divisions among employers and labour. In adapting regulatory and institutional systems, the overarching challenge facing the Nordic stakeholders is to strike the right balance between the quests for growth and innovation, on the one hand, and for equality and institutional stability, on the other.

It is not hard to imagine that the individualized, task-based organization of work presently characterizing the sharing economy can reinforce tendencies of fragmentation in the Nordic labour markets. And, if it gains momentum, it can in the longer run usher in disruptive institutional change. On the other hand, given the historical adjustment capacity of the Nordic labour markets and their legacy of negotiated self-regulation, one can also envisage a path of evolutionary change where work through sharing economy platforms is pragmatically incorporated in the associational institutions of the Nordic models.

Hence, the emergent sharing economy does not only call for further analyses of processes of renewal and change in Nordic working life; it offers intriguing opportunities to study how the various political and organized stakeholders in the Nordic models assess and approach the evolution of novel modes of production with potential to threaten parts of their core constituencies and alter established forms of interest intermediation. Unfolding in parallel in all Nordic countries, this provides a seldom chance to study how path-breaking technology and market driven change interacts with institutional and political dynamics in reshaping the conditions for work and production in the Nordic societies.

By taking stock of existing knowledge, a basic purpose of the pilot project was to provide a better basis for developing research questions and empirical approaches for more elaborate, comparative follow-up studies of the platform economy's implications for Nordic working lives in the years to come. In Table 2 we have highlighted a few key themes where closer studies and process tracing are needed to develop a more qualified understanding of the Nordic platform economies' volume, dynamics, and consequences, and how Nordic political and social actors respond in order to facilitate and shape its further evolution. 

market implications

\section{Topics for further studies}

Theme 1 Mapping the size, structure, and actors of the platform labour markets

A) The platform companies: Traits, turnover, and evolution? Main customer groups?

B) The platform workers: Who, why, and which skills? How much do they work, and under what conditions?

C) The job market: Size, job composition, mobility/networks, matching, and functioning?

Theme 2 Governance and renewal of regulatory and institutional frameworks

A) Government initiatives: Changes in regulations, institutions, tools \& modes of governance?

B) Evolving EU frameworks: How do they affect Nordic countries?

C) Coalitions and conflicts: Social partner strategies? New actors and forms of self-organization or self-regulation?

D) Labour law developments: Redrawing legal boundaries?

Theme 3 Synthetical analyses and assessments of issues such as: Varieties and commonalities of platform economy trajectories in the Nordic countries? Main factors accounting for observed developments and variations in its labour market implications? How and what can national actors learn from experiences and strategies in the other Nordic countries?

Within each of these main themes there are plenty of interesting and relevant issues that could be addressed, and other themes might well have been mentioned. Yet, given the limitations in the access to adequate data, statistics, and research funding in this area, it would at this stage be a great advantage if the Nordic institutions contributed to a concentration of research efforts on common key themes where more basic empirical work is needed to provide an adequate knowledge base for policy formation, development of comparable statistics, and further research. Methodologically, the Nordic countries do as institutionally "most similar cases", with interesting differences in specific policy areas, lend themselves to comparative studies of the national pathways into the platform economy. Such studies can also provide valuable contributions to international knowledge about the broader institutional and societal dynamics that shape the digitalization of work. 


\section{Norsk Resumé}

I denne rapporten presenterer vi en foreløpig kunnskapsstatus om konsekvensene av delingsøkonomien for arbeidsmarkedet og arbeidslivsrelasjoner i de nordiske landene. Vi ser også nærmere på hvordan partene i arbeidslivet og myndighetene tilnærmer seg delingsøkonomien og spørsmål knyttet til regulering, beskatning og konkurransevilkår. Så langt er det lite tilgjengelig statistikk og forskning på dette feltet. Arbeid via digitale plattformer er fortsatt marginalt i det nordiske arbeidsmarkedet, men hvis det "tar av" kan det utfordre den nordiske arbeidslivs- og velferdsmodellen som er organisert rundt arbeidstakerforholdet. Sysselsettingspotensialet og konsekvensene av delingsøkonomien vil blant annet avhenge av hvordan myndighetene og partene i arbeidslivet svarer på de ulike utfordringene. Så langt har de sentrale aktørene vært i en sonderingsfase preget av kunnskapsinnsamling, diskusjon og refleksjon om mulige politikkalternativer, hvor de har trådd forsiktig for ikke å hindre utviklingen av delingsøkonomien. Framveksten av delingsøkonomien og dens arbeidsmarkedskonsekvenser gir en unik mulighet til komparative studier av hvordan endringer i teknologi og markeder påvirker politikkutviklingen innenfor et kjerneområde i den nordiske modellen. Rapporten konkluderer med å peke på kunnskapshull og temaer for oppfølging i videre studier. 



\section{Bibliography}

Alsos, K., Jesnes, K., Øistad, B.S., Nesheim, T. (2017). Når sjefen er en app. Fafo-rapport 2017:41.

Aftenposten (20.10.2016). Uber-sjåfører i Oslo risikerer både førerkortet og bruksforbud for bilen. http://www.aftenposten.no/norge/Uber-sjaforer-i-Oslo-risikerer-bade-forerkortet-ogbruksforbud-for-bilen-607178b.html

Aftenposten (16.12.2016). Taxisjåfør fratatt førerkortet etter 1100 Uber-oppdrag. Politiet har slått til mot minst 70 Uber-sjåfører. http://www.aftenposten.no/norge/Taxisjafor-fratattforerkortet-etter-1100-Uber-oppdrag-Politiet-har-slatt-til-mot-minst-70-Uber-sjaforer$610413 \mathrm{~b} . \mathrm{html}$

Andersen, S. K., Dølvik, J. E., \& Ibsen, C. L. (2014). De nordiske aftalemodeller i åbne markederudfordringer og perspektiver. Nordmod2030. Delrapport 9. Fafo-rapport 2014:08.

Andreassen. T. W. (2016). «Delingsøkonomien - et gode eller et onde? (Sharing economy - a good or an evil?) Lecture at NHO Abelia conference on the sharing economy, March 3, 2016.

Beck, U., \& Beck-Gernsheim, E. (2002). Individualization. London: Sage.

Becker, L., (2017). Cool Company - creating a hassle-free worklife. Presentation at the conference Shaping the Future of Work in the Nordic Countries - the Impacts of the Sharing Economy and New Forms of Work, Oslo 23rd of May, 2017.

Berg, L. \& Kjørstad I. (2017). Delingsøkonomien I Norge - forbrukere of tilbyderes vurderinger av markeder I vekst. Oslo: SIFO.

Berg, J. (2016). Income security in the on-demand economy: Findings and policy lessons from a survey of crowd workers. Working paper. Conditions of Work and Employment Series No. 74. International Labour Organisation.

Bjørnstad, R. (2017). How do we meet digitalization? Presentation at the conference Shaping the Future of Work in the Nordic Countries - the Impacts of the Sharing Economy and New Forms of Work, Oslo 23rd of May, 2017.

Botsman, R. (2013). The Sharing Economy lacks a shared definition.

http://www.fastcoexist.com/3022028/the-sharing-economy-lacks-a-shared-definition

Braunerhjelm, P., \& Eklund, J. (Eds.) (2014). En fungerande arbetsmarknad - Nyckeln till innovation och kunskapsdriven tillväxt. Stockholm: Entreprenörskapsforum.

British government, Independent report Unlocking the sharing economy: independent review, Department for Business, Innovation \& Skills First published: 26 November 2014

Broughton et al. (2016). Precarious Employment in Europe (Volume 1: Patterns, Trends and Policy Strategies; Volume 2: Country Case Studies).

CEVEA (2015). Digitale trends og det danske arbejdsmarked. Analyse. Copenhagen.

CJEU, Case C-434/15,

http://curia.europa.eu/juris/document/document.jsf?text=\&docid=198047\&pagelndex=0\&docl ang $=E N \&$ mode $=$ req $\&$ dir $=\&$ occ $=$ first $\&$ part $=1 \&$ cid $=58794$

Dagens Næringsliv (11.05.2016). Uber stopper omstridt tjeneste i Sverige - fortsetter i Norge. http://www.dn.no/grunder/2016/05/11/1444/Uber/uber-stopper-omstridt-tjeneste-i-sverigefortsetter-i-norge

Danish government (2017). Deleøkonomi i Danmark. Strategi for vækst gennem deleøkonomikort fortalt. Regeringen. October 2017.

Dansk Taxi Råd et al. (2015). Revision af taxiloven - brancheopfordring. October 30, 2015. Copenhagen. 
Degryse, C. (2016). Digitalisation of the economy and its impact on labour markets. Etui. Working Paper 2016.02. https://doi.org/10.2139/ssrn.2730550

Demil, B., \& Lecocq, X. (2006). Neither market, nor hierarchy or network: The emergence of bazaar governance. Organization Studies, 27(10), 1447-1466.

https://doi.org/10.1177/0170840606067250

Durkheim, E. (1893). The Division of Labour in Society. New York: Free Press, 1997.

Dølvik, J. E., \& Jesnes, K. (2016). The sharing Economy - towards a matching revolution in the markets for work? Presentation/interim report from Fafo pilot study. EKA, Nordic Council of Ministers, Copenhagen, 11.10.2016.

Dølvik, J.E., \& Jesnes, K. (2017). Nordic labour markets and the sharing economy - report from a pilot project. TemaNord 2017:508.

Dølvik, J. E., Fløtten, T., Hippe, J. M., \& Jordfald, B., (2014). Den nordiske modellen mot 2030.Et nytt kapittel? Nordmod2030 Sluttrapport. Fafo-rapport 2014:46.

Dørum, $\varnothing$. (2017). Man against machine: Does technology steal our jobs? Presentation at the conference Shaping the Future of Work in the Nordic Countries - the Impacts of the Sharing Economy and New Forms of Work, Oslo 23rd of May, 2017.

Einav, F., \& Levins J. (2015). Peer-to-Peer Markets. Working paper. https://doi.org/10.3386/w21496

Erichsen (2015). Deleøkonomi 2015 - når forbrugerne deler/bytter/udlejer deres ting og tjenester med andre forbrugere. Nordea. https://www.nordea.com/lmages/3487433/Dele\%C3\%B8konomi\%20-\%20data\%2ofra\%20Gallup,\%202015.pdf

Eriksson, K. (2017). Work Environment Rules -Regulations for a Modern Working Life, Presentation at the conference Shaping the Future of Work in the Nordic Countries - the Impacts of the Sharing Economy and New Forms of Work. Oslo, 22nd of May.

EU Commission. (2016) Communication from the Commission to the European Parliament, the Council, the European Economic and Social Committee and the Committee of the Regions - A European Agenda for the collaborative economy. Brussel, 2.6.2016.

Eurofound (2015). New forms of employment. Authors: Mandl, Irene; Curtarelli, Maurizio; Riso, Sara; Vargas, Oscar; Gerogiannis, Elias. Report: EF1461, 2015.

Evju, S. (2012). «Trepartsrelasjoner» i arbeidsretten? Working Papers in Labour Law 2012:3. University of Oslo.

Fellman, A. (2015) in SOU 2015:65, Om Sverige i framtiden - en antologi om digitaliseringens möjligheter, Delbetänkande av Digitaliseringskommissionen, Stockholm.

Gabrielsen, T.S. (2017) The sharing economy-disruptive change or incorporation in the Nordic model? Presentation at the conference Shaping the Future of Work in the Nordic Countries the Impacts of the Sharing Economy and New Forms of Work. Oslo, 22nd of May.

Harris, S. D., \& Kreuger, A. B. (2015). A Proposal for Modenizing Labor Laws for Twenty-First Century Work: The "Independent Worker". Discussion Paper 2015-10, the Hamilton project. Brookings, DC.

Hotvedt, M. J. (2016). Arbeidsgiveransvar i formidlingsøkonomien? Tilfellet Uber. Lov og rett, 55(8).

Hotvedt, M. J. (2017). Rethinking the regulatory frameworks of work, employers, and labour relations. Presentation at the conference Shaping the Future of Work in the Nordic Countries - the Impacts of the Sharing Economy and New Forms of Work. Oslo, 23rd of May, 2017.

Hotvedt, M.J. (forthcoming). The Contract of employment-test renewed. A Scandinavian approach to platform work.

Huws, U., \& Joyce, S. (2016a). Size of Sweden's "Gig Economy" revealed for the first time. http://www.uni-europa.org/wp-content/uploads/2016/o3/crowd-working-surveyswedenpdf.pdf

Huws, U., \& Joyce, S. (2016b). Size of the UK's Gig Economy' revealed for the first time. http://www.feps-europe.eu/assets/a82bcd12-fb97-43a6-9346-24242695a183/crowd-workingsurveypdf.pdf 
Huws, U., \& Joyce, S. (2016c). Character of Austria's "Gig Economy" revealed for the first time. http://www.uni-europa.org/wp-content/uploads/2016/og/crowd_working_survey_Austria.pdf

Huws, U., \& Joyce, S. (2016d). New estimate of the size of Dutch "Gig Economy" http://www.fepseurope.eu/assets/778d57dg-4e48-45fo-b8f8-18gda359dc2b/crowd-working-surveynetherlands-finalpdf.pdf

Håkansson, K., Isidorsson, T., \& Kantelius, H. (2013). Stable flexibility. Strategic long term use of temporary agency workers in Sweden. International Journal of Action research, 9(3).

Ilsøe, A. (2016), Digitalization of service work and social partner responses. Presentation at the 8th Annual TURI Conference, May 11-13, 2016 Sesimbra, Portugal.

Ilsøe, A. \& Madsen L.W. (2017). Digitalisering af arbejdsmarkedet. Danskernes erfaring med digital automatisering og digitale platforme. FAOS: 157.

Ilsøe, A., Larsen, T. P. \& Felbo-Kolding, J. (2017) Living hours under pressure: flexibility loopholes in the Danish IR-model, Employee Relations, 39:6 pp 888-910.

Ilsøe (2017a). Hello or goodbye to the institutions for collective governance of labour markets in the Nordic countries? Presentation at the conference Shaping the Future of Work in the Nordic Countries - the Impacts of the Sharing Economy and New Forms of Work. Oslo, 23rd of May, 2017.

Ilsøe, A. (2017b). The digitalisation of service work - social partner responses in Denmark, Sweden and Germany. TRANSFER - European Review of Labour and Research. 23, 3, p. 333-348.

Insightlab. (2015). Insightrapport, Den nya Arbetsmarknaden - mot en "gigekonomi" med ökad flexibilitet och matchning. Report nr. 5, 2015.

Iversen, N. M., \& Hem, L.E. (2016). Markedsføring og delingsøkonomi. Magma, 6/2016, 49-59.

Jesnes, K., \& Nesheim, T. (2015). Formidlingsøkonomi, ikke delingsøkonomi. Aftenposten, 19.11.2015.

Jesnes, K., \& Nesheim, T. (2015b). Nye arbeids- og organisasjonsformer - myte eller realitet? Presentation for a seminar on various forms of association, organized by the Ministry of Labour and Social Affairs. 19 November 2015, Oslo.

Jesnes, K., Nesheim, T., \& Dølvik J. E. (2016b). New ways of organizing work - the sharing economy and its impact on the Norwegian labour market. Paper presented at the ILERAconference, Milano, 8-10. Sept. 2016.

Jesnes, K., Øistad, B. S., Alsos K., \& Nesheim T. (2016a). Aktører og arbeid i delingsøkonomien. Delrapport. Fafo-notat 2016:23.

Juel, S. (2016). Delingsøkonomi - hva er egentlig nytt? Civita-notat, nr. 9: 2016.

Kalleberg, A. L., \& Dunn, M. (2016). Good Jobs, Bad Jobs in the Gig Economy. The University of North Carolina at Chapel Hill.

Kapital (2017). Genierklært delingsøkonomi, skatteunndragelse og trygdebedrageri: Ubers svarte reise. Kapital 18/2017. Siri Gedde-Dahl.

Klassekampen (22.12.2016). Esas støtte til Uber i en EU-høring provoserer flere EUmotstandere. Undres over Uber-støtte.

Krokan, A. (2015). Tosidige markeder og disruptive innovasjoner. Utdrag fra kap. 7 «Verdiløse prosesser, nye mellomledd og nettverk» i boken «Det friksjonsfrie samfunn».

Lag om transportservice, 320/2017, https://www.finlex.fi/sv/laki/alkup/2017/20170320.

Lakhani, K.R., \& Panetta, J. A. (2007). The Principles of Distributed Innovation. Innovation, 2(3), 97-112. https://doi.org/10.1162/itgg.2007.2.3.97

Lee, M.K., Kusbit, D., Metsky, E., Dabbish, L. (2015). Working with Machines: The Impact of Algotithmic and Data-Driven Management of Human Workers.

Ljungberg, J. (2000). Open source movements as a model for organising. European Journal of Information Systems, 9(4). https://doi.org/10.1057/palgrave.ejis.3000373

LO (2016a). Plattformsøkonomi - lovgivningsmæssige udfordringer og fagbevægelsens løsningsforslag. 3.5.2016. Copenhagen.

LO (2016b). Notat om samhandlingsøkonomien. Oslo, June 2016.

London Employment Tribunal (2016), Case no: 2202551/2015 \& Others. 
Munkøe, M., Ravn, J., \& Christensen, G. L. (2015). Deleøkonomien på fremmarch. Dansk Erhvervs Perspektiv 2015:21.

Nergaard, K. (2016). Tilknytningsformer i norsk arbeidsliv-nullpunktsanalyse. Fafo-rapport 2016:07.

Nordea (2016). Deleøkonomi 2016. www.nordea.com. Copenhagen.

North California District Court, Case 3: 13-cv-03426oEMC, 11 March 2015.

NOU 2017:4: Delingsøkonomien - muligheter og utfordringer. Report from the committee appointed by Royal Decree March 4, 2016. Issued to the Ministry of Finance, 6 February 2017.

Olsen, K. (2015). Når jobben ikke lenger er et sted (When work is no longer a place). Lecture at a conference about the new work life the Waterfront Ideas in Oslo, 13.08.2015.

Politiken (30.09.2016). Skat vil give opplysninger om Uber-chauffører til politiet. http://politiken.dk/indland/ECE3407148/skat-vil-give-oplysninger-om-uber-chauffoerer-tilpolitiet/

Pärnanen, A. \& Sutela, H. (2014). Self-employed without employees, Statistics Finland.

Pärnänen, A., \& Sutela, H. (2013). Itsensä työllistäjät Suomessa. Tilastokeskus.

Pedersen, S., Haavardsholm, O. \& Vennemo, H. (2016). Delingsøkonomiens betydning for norsk økonomi i dag og i fremtiden. Vista analyse rapport $\mathrm{nr} .45$.

Pokorny, A (2017). Towards a European pillar of social rights, new forms of work, and the sharing economy. Presentation at the conference Shaping the Future of Work in the Nordic Countries the Impacts of the Sharing Economy and New Forms of Work. Oslo, 22nd of May, 2017.

Prassl, J., \& Risak, M., (2016). Uber, Taskrabbit, \& Co: Platforms as Employers? Rethinking the Legal Analysis of Crowdwork (February 16, 2016). Comparative Labor Law \& Policy Journal. Forthcoming; Oxford Legal Studies Research Paper No. 8/2016. Available at SSRN: https://ssrn.com/abstract=2733003

Prassl, J. (2017). Rethinking work in the on-demand economy, Presentation at the conference Shaping the Future of Work in the Nordic Countries - the Impacts of the Sharing Economy and New Forms of Work, Oslo 22nd of May, 2017.

Prassl, J. (2018). Humans as a Service. The Promise and Perils of Work in the Gig Economy. Oxford University Press.

Redder, G. (2016). Danskerne utrygge ved at tage job på nye digitale platform. Ugebrevet A4, 24 October 2016.

Regeringen. (2016). Et stærkere Danmark Vækst 2016. August 2016.

Rochet, J. C., \& Tirole, J. (2006). Two-sided market: a progress report. The RAND Journal of Economics, 37(3), 645-667. https://doi.org/10.1111/j.1756-2171.2006.tbooo36.x

Rolandsson, B., Bergquist, M., \& Ljungberg, J. (2011). Open source in the firm: Opening up professional practices of software development. Research Policy, 40(4), 576-587. https://doi.org/10.1016/j.respol.2010.11.003

Siltala, J. (2016). Työnantajan alaisena ilman työsuhdetta. Kalevi Sorsa säätiö.

Slettemeås, D., \& Kjørstad, I. (2016). Delingsøkonomien i Norge: En studie av befolkningens erfaringer og holdninger knyttet til deling, gjenbruk, digitale delingsplattformer og brukerevalueringer. Oppdragsrapport nr. 3-2016. Oslo: SIFO.

SOU 2017: 24. Ett arbeidsliv i förändring - hur påverkas ansvaret för arbetsmiljön. SOU 2015:91. Digitaliseringens transformerande kraft - vägval för framtiden.

Staab, P. (forthcoming 2017). The consumption dilemma of digital capitalism Transfer, 23(2).

Stefano, V. D. (2016). The Rise of the "just-in-time workforce": On-demand work, crowdwork and labour protection in the "gig-economy". In ILO (ed.), Conditions of work and employment series. Geneve.

Summers, L. (2016). The Age of Secular Stagnation: What It Is and What to Do About It. Foreign Affairs, February 201. http://larrysummers.com/2016/02/17/the-age-of-secular-stagnation

Sundararajan, A. (2016). The Sharing Economy. The End of Employment and the Rise of Crowdbased Capitalism. The MIT Press Cambridge Massachusetts. 
Svansø, V. L. (2016). Yngre medlemmer af fagforbundet HK er åbne over for en ny økonomi og et nyt arbejdsmarked, hvor de skal finde job som digitale selvstændige via apps og hjemmesider. Berlingske Business (business.dk). 24.10.2016.

Söderqvist, F. (2017). Unionen om plattformsekonomin och den nya arbetsmarknaden, Presentation at the conference Shaping the Future of Work in the Nordic Countries - the Impacts of the Sharing Economy and New Forms of Work. Oslo, 22nd of May, 2017.

Söderqvist, F. (2016). Plattformsekonomin och den Svenska partsmodellen. Stockholm: Unionen.

Taylor, M., Marsh, G., Nicol, D., Broadbent, P. (2017). Good Work: The Taylor review of modern working practices.

Ugeavisen A4, 8 June 2017 Fatamorgana eller Fremtiden? Regnskabstal afslører: Deleøkonomi I Danmark er kun en sårbar baby.

Visser, J., \& Hemerijck, A. (1997). A "Dutch Miracle". Job Growth, Welfare Reform and Corporatism in the Netherlands. Amsterdam University Press.

https://doi.org/10.5117/9789053562710

$\varnothing$ degaard, A. M. (2016). Stor usikkerhet om delingsøkonomien blant tillitsvalgte. Arbeidslivet.no 28.06.2016.

\section{Country reports}

Jesnes K., \& Dølvik J. E. (2016). Nordic labour markets and the sharing economy: National Background Reports. Nordic Working Papers, 2017:904.

Ólafsdóttir, K. (2016). Sharing economy in the Nordic Countries - Country report from Iceland. Rasmussen, S., \& Madsen, P. K. (2016). Sharing economy in the Nordic Countries - Country report from Denmark.

Rolandsson, B., Petersson J., \& Berglund, T. (2016). Sharing economy in the Nordic Countries Country report from Sweden. University of Gothenburg, Sweden.

Saloniemi, A. (2016). Sharing economy in the Nordic Countries - Country report from Finland. 
Nordic Council of Ministers

Ved Stranden 18

DK-1061 Copenhagen K

www.norden.org

\section{Nordic labour markets and the sharing economy}

This report presents a preliminary knowledge status about implications of the sharing economy for labour markets and employment relations in the Nordic countries. It also reviews how the Nordic countries and their social partners approach the sharing economy and issues relating, amongst other, to its legality, regulation, taxation, and terms of competition. There is so far scant supply of statistics, data and research in this field. The employment potentials and consequences of the sharing economy will, amongst other, depend on the governments' and the organized actors' responses to these challenges. Currently, all the actors seem to be in a phase of knowledge gathering and deliberation of possible policy options, cautiously avoiding taking steps that might obstruct the development of the sharing economy. 